\title{
The potential impact of enforced lease capitalisation in the UK retail sector
}

\begin{abstract}
Alan Goodacre*
August 2001

Abstract

The main objective of the paper is to assess the potential economic consequences of the G4+1 proposed changes to lease accounting by examining companies in the UK retail sector over the 1994-99 period. The magnitude of the impact of lease capitalisation is assessed by examining the effect on nine key accounting ratios that are used in decision-making and in financial contracts. A 'constructive capitalisation' procedure is used to estimate the unrecorded lease liability and asset.
\end{abstract}

Operating lease finance is shown to be very important in the retail sector, with a long-term liability approximately 3.3 times higher than on-balance sheet long-term debt; by contrast, finance leases are immaterial. Operating leased assets, the major part of which is 'land and buildings' (98\%), represent a significant proportion (28\%) of reported total assets. Capitalisation of operating leases would have a major impact on all nine ratios. Further, the ranking of companies changes markedly for asset turnover, interest cover and the three capital-based gearing measures, and especially for general retailers.

Using credit-risk adjusted discount rates would lessen slightly the impact of capitalisation, but would have little impact on intra-sector ranking of company performance. Anticipation of future lease rental increases would have a significant impact on the level of operating lease assets/liabilities and on profit after tax. While the use of renewable short lease contracts (or break clauses) would reduce the level of operating lease assets and liabilities, substantial amounts would remain to be reported on-balance sheet.

These findings contribute to the assessment of the economic consequences of a policy change requiring operating lease capitalisation. Prior research suggests that individual users of financial statements are not efficient information processors, and also that company managers do not believe that users, even in aggregate (e.g. the stock market) are efficient processors. Consequently, the significant changes in the magnitude of key accounting ratios and the major shift in company performance rankings suggest that interested parties' economic decisions are likely to be affected.

* Alan Goodacre, Dept. of Accounting, Finance and Law, University of Stirling, Stirling FK9 4LA, UK (email: Alan.Goodacre@stir.ac.uk).

Acknowledgements

The financial support of the University of Stirling Faculty of Management Research Fund is gratefully acknowledged. 


\section{The potential impact of enforced lease capitalisation in the UK retail sector}

\section{INTRODUCTION}

Leasing represents a significant source of finance for many companies. Total lease finance used by non-financial industrial and commercial UK listed companies was estimated in 1994 to be approximately $£ 71$ billion. ${ }^{1}$ This was about half the level of the companies' longterm debt finance and financed about $28 \%$ of their net fixed assets. In 1999, new business leasing by members of the Finance \& Leasing Association represented $15.3 \%$ of the total investment in equipment (Finance \& Leasing Association, 2000). In the UK, leasing is currently governed by accounting standard SSAP 21 'Accounting for leases and hire purchase contracts', which was issued in 1984 (ASC, 1984). Since its introduction, there has been a considerable growth in the use of off-balance sheet operating leases (Goodacre \& Beattie, 1999) and this has encouraged accounting standard setters to review the working of the standard and to propose major changes. This culminated in a G4+1 discussion paper 'Leases: Implementation of a New Approach' (ASB, 1999), which adopts a 'property rights' perspective and proposes that all leases should be recognised on the balance sheet.

Leases have been shown to be a major source of finance in the UK, with operating leases dominating finance leases in importance, measured by the value of assets financed (Beattie, Edwards \& Goodacre, 1998, (hereafter BEG)). The predominance of operating leases illustrates the shift from finance leases to operating leases that was anticipated by managers at the time SSAP21 was introduced (Taylor \& Turley, 1985; Drury \& Braund, 1990). In the US, Imhoff \& Thomas (1988) document similar 'economic consequences' as company managers switched to operating leases (and non-lease finance) around the time of implementation of SFAS 13.

As a result of the different accounting treatments, the classification of leases has important implications for reported levels of indebtedness and for standard performance measures. Profit margins, return on assets and gearing measures would all be significantly affected if operating leases were required to be recognised on the lessee's balance sheet rather than merely disclosed in a footnote (BEG, 1998; Imhoff, Lipe \& Wright, 1991 (hereafter ILW)). The use of operating leases, and therefore also the potential impact of lease capitalisation varies both across broad industry sectors and within each sector. The impact is particularly acute in high usage areas such as the services sector. In particular, the retail sub-sector has been identified as one that undertakes more operating leasing than average (Dresdner Kleinwort Benson, 1998, (hereafter DKB); Beattie, Goodacre \& Thomson, 2000a). Retail assets are good candidates for operating leases; they are relatively standard assets (rather than firm-specific), mainly land and buildings ${ }^{2}$, with relatively low 'residual value risk' making them attractive to lessors.

The main objective of this paper is to provide evidence that will assist in assessing the economic consequences of a change in the regulation of lease accounting, as proposed in the G4+1 discussion document (ASB, 1999). The potential impact of the change on performance measures such as accounting ratios within the UK retail sector is assessed. Three further aspects of the proposed accounting changes are separately investigated. First, the effect of using a credit-risk adjusted interest rate, rather than a risk-free rate, to discount lease rental payments is assessed. Second, the contentious issue of the treatment of leases with rentals that rise in line with prices (e.g. traditional upward-only rent review leases on UK property) is explored. Third, the use of renewable short-term lease contracts (or break 
clauses) to mitigate the impacts of capitalisation is modelled and the differential impact is measured. The study represents policy-relevant ex ante research in support of the standardsetting process of the type advocated by Schipper (1994).

The remainder of the paper is structured as follows. After a discussion of the current and proposed methods of accounting for leases, section two provides a review of relevant literature including various approaches to the assessment of economic consequences. Section three outlines the methods employed in the current study, including sample and data collection procedures. The results and discussion are presented in section four and are followed by a summary and conclusion.

\section{Accounting for leases: current and proposed}

SSAP 21 identifies two types of lease and requires a radically different accounting treatment for each. A lease that transfers to the lessee substantially all the risks and rewards of ownership is a finance lease and is treated as an 'in substance' purchase by the lessee and sale by the lessor. Accordingly, an asset is shown on the lessee's balance sheet at the present value of the minimum lease payments and a corresponding liability is recognised. On the other hand, a lease which does not transfer substantially all the risks and rewards of ownership to the lessee is deemed to be an operating lease. Under an operating lease the whole of the leased property is treated as an asset of the lessor and the lessee simply recognises the rental payments as an expense, with limited additional footnote disclosure of future lease rental commitments. Internationally, other existing leasing standards such as IAS 17 (revised 1997) and FAS 13 in the USA are based on similar concepts to SSAP 21 in relation to distinguishing finance leases from operating leases.

In 1996, the G4+1 published a special report entitled Accounting for Leases: A New Approach (McGregor, 1996). This identified several fundamental deficiencies in current lease accounting standards. First, they omit material assets and liabilities arising from 'offbalance sheet' operating lease contracts. Second, marginal differences in contractual terms can result in one lease being claimed as a finance lease and another as an operating lease and thus similar transactions do not receive the same accounting treatment. Third, the 'all or nothing' approach to the capitalisation of leased assets does not adequately reflect modern complex transactions. The report went on to explore a conceptual approach to lease accounting, recommending that new standards should be developed that would remove the distinction between finance leases and operating leases and would require lessees to recognise as assets and liabilities all material rights and obligations arising under lease contracts.

More recently, the ASB published a discussion paper Leases: Implementation of a New Approach (ASB, 1999), in which the G4+1 develops the approach recommended in the special report. This recommends that all leases should be reflected in financial statements in a consistent manner and it explores the principles that should determine the extent of the assets and liabilities that lessees and lessors would recognise under leases. Under the recommended approach, at the beginning of a lease the lessee would recognise an asset and a liability equivalent to the fair value of the rights and obligations that are conveyed by the lease (usually the present value of the minimum payments required by the lease). Thereafter, the accounting for the lease asset and liability would follow the normal requirements for accounting for fixed assets and debt. The lessor would report financial assets (representing amounts receivable from the lessee) and residual interests as separate assets. The principles for accounting for more complex features of lease contracts including 
renewal options, contingent rentals, residual value guarantees and sale and leaseback transactions are also examined.

All the G4+1 organisations have published the discussion paper in their own jurisdictions but, further progress on accounting standards is likely to be slow. Even in the UK where there has been strong commitment to the project, the ASB has acknowledged that 'because of the complexity of the issues arising and the concerns expressed by some respondents, it will take some time for the Board to consider all of the points raised. Therefore, an exposure draft of a new accounting standard is unlikely to be published until late 2001' (ASB, 2001).

The proposals are controversial and have already generated significant negative response from some who fear that there will be major economic consequences if the proposals are adopted. For example, the Finance \& Leasing Association issued a press release 'Think again Sir David: lease accounting reform is not as simple as you think', in which they suggested that the proposals 'would have complex and dramatic effects on the financing of British business' and 'will be damaging to many companies' balance sheets' (Finance \& Leasing Association, 1999). KPMG suggested that 'there seems little merit in replacing one set of arbitrary rules with another' (KPMG, 2000). The real estate industry is also concerned about the impact on the sector. It has argued that the proposals 'will increase the occupiers reluctance to enter into long term commitments, leading to a further and more rapid demand for flexible arrangements' and that in the period of uncertainty surrounding discussion of the proposals 'decision making will be difficult and this may create a substantial slowdown in the letting market' (Investment Property Forum, 1999).

\section{LITERATURE}

During the late 1970's, accounting regulators became increasingly aware that economic consequence arguments were being used explicitly in the standard-setting process and became sensitive to the 'economic consequences' of a change in accounting method on the behaviour of the various users (Zeff, 1978). Holthausen \& Leftwich (1983) discuss the predictions of economic consequence theories in terms of contracting and monitoring costs and provide a review of the early empirical work. More recently, Blake (1992) has suggested a classification system for economic consequences based on impacts that arise from users' decision making and those that arise from the mechanistic application of regulations or contracts. Since the late 1970's, the potential impact of changes in accounting standards on interested parties has become an important influence on decisions by standard setters world-wide. Indeed, the constitutions of standard-setting bodies such as the Accounting Standards Board (UK), the Financial Accounting Standards Board (US) and similar bodies reflect this by seeking direct representation from the various constituencies of interested parties, including users, in the standard-setting process. Similarly, the process itself enables interested parties to contribute formally at various stages from initial discussion paper through exposure draft to promulgation of a final accounting standard. Typically, this will be augmented by informal discussions between standard-setters and constituency-groups.

Whilst the principle of giving due weight to 'economic consequences' has become well established, the practice of identifying and measuring potential (ex ante) and actual (ex post) economic consequences is fraught with difficulties. Several different approaches have been adopted. First, the direct link between accounting changes and firm response has been investigated, usually by an ex post analysis of reported accounting numbers, to infer responses attributable to new accounting standards (e.g. R\&D: Dukes, Dyckman \& Elliot, 
1980; Horwitz \& Kolodny, 1980; Elliot et al. 1984; Shehata, 1991). Second, an indirect approach has been chosen, involving the analysis of market reaction to accounting changes, usually using the 'event study' methodology (e.g. pensions: Gopalakrishnan \& Sugrue, 1992; oil and gas: Larcker \& Revsine, 1983; R\&D: Dukes, 1976; Vigeland, 1981; Wasley \& Linsmeier, 1992; leasing: Ro, 1978; El-Gazzar, 1993). Third, ex post surveys of users' perceptions of the impact of accounting changes have been undertaken (e.g., R\&D in the UK: Ball, Thomas, \& McGrath, 1991), as well as ex ante surveys of interested parties' views on potential accounting changes (see below).

Several studies have considered previous changes in accounting for leases, mainly in the US environment. Abdel-khalik (1981) carried out a detailed ex post study of the economic consequences on US lessees of the changes in lease accounting caused by SFAS 13 (enacted in 1976) as part of the FASB post-enactment review of the statement. The study analysed changes in the financial statements themselves, assessed the market risk impact on equity and debt, and undertook a mail survey of attitudes to the changes. The study found that company management responded to the standard by structuring new lease contracts, and renegotiating existing lease contracts, to avoid capitalisation of leases. There was evidence that more assets were bought, or constructed, instead of being leased and also evidence of changes in capital structure. Three possible reasons for this reaction by company managers were proposed: managers' belief that users are informationally inefficient, the impact on managers' compensation, and the avoidance of debt covenant violation. While there was no substantive evidence of adverse market reaction to the standard, some company managers expressed concern that users' evaluations are often influenced by cosmetic accounting changes. When asked about possible future changes to lease accounting based on a property rights perspective, users responded positively, but company managers negatively, toward capitalising all non-cancellable leases.

Imhoff \& Thomas (1988) examined capital structure changes in response to SFAS 13 and found that the standard had a significant impact on lessees. They document a systematic substitution from finance (capital) leases to operating leases and non-lease sources of finance, suggesting that re-negotiation of lease contracts is a relatively low-cost alternative for mitigating the financial statement effects. In addition, lessees appeared to reduce book leverage by increasing equity and reducing conventional debt. Australian firms also responded to the new lease accounting rules by reducing their reliance on finance leasing and increasing their use of non-lease debt and equity. However, in contrast with the US, they did not appear to have renegotiated finance lease contracts to operating leases (Godfrey \& Warren, 1995). For the similar changes brought about by SSAP21 in the UK, Garrod (1989) found weak evidence that the market reacted to the new information available postSSAP21 and also that managers reacted to the standard by reducing their non-lease debt prior to first disclosure of their lease information.

Two, non-mutually exclusive, approaches have been adopted in the ex ante assessment of the likely economic consequences of proposed lease accounting changes. First, company managers' and other interested parties' views have been solicited directly using questionnaire surveys. Taylor \& Turley (1985) investigated the opinions of UK management on lease accounting following ED29, the exposure draft that preceded SSAP21. They found that only a minority of managers believed that internal financing or investment decisions would be significantly affected by the proposed accounting standard. However, managers believed that users' decisions, including risk assessment, were likely to be affected, suggesting that managers' behaviour could be influenced by information inductance (Prakash \& Rappaport, 1977). Managers also anticipated that future lease 
contracts would be structured as operating leases to avoid capitalisation; a similar response was reported by Drury \& Braund (1990) in their (post-SSAP21) general survey of the leasing decision.

Recently, Beattie, Goodacre \& Thomson (2001a) surveyed UK finance directors on the G4+1 proposals for lease accounting reform. They found that respondents recognised that additional assets and liabilities would be brought on to the balance sheet under the new proposals and that this would impact on reported gearing. This was considered likely to lead to the need to re-negotiate borrowing covenants, and to a reduction in credit ratings for some companies. It was also accepted that this would improve the evaluation of long-term financial commitments and company comparisons. Additional compliance costs and administrative burdens relating to lease accounting were anticipated by respondents. The finance directors believed that lease terms would become shorter to minimise balance sheet obligations and also that the proposals would make lease finance less attractive. However, they did not believe that the proposals would substantially change the UK property market. In particular, the purchase of property rather than leasing was considered unlikely, probably because the purchase alternative is seldom available.

The second approach to ex ante assessment of economic consequences involves estimating the impact of lease capitalisation on accounting numbers used as performance measures (e.g. accounting ratios). Economic consequences can be inferred if the changes in performance measures are likely to lead to changes in the decision-making behaviour of users and/or company managers. The validity of this inference is dependent either on users being 'inefficient' in their information processing or on managers believing them to be so. Thus, it is also necessary to have evidence of users' processing of lease accounting information and/or of managers' perceptions of this.

The evidence on users' processing of lease accounting information is somewhat conflicting. Most studies find that individual users appear to be influenced by whether the information is recognised in the financial statements or merely disclosed in the footnotes to the accounts (Wilkins \& Zimmer, 1983b; Munter \& Ratcliffe, 1983; Breton \& Taffler (1995); Gopalakrishnan \& Parkash, 1996), but some studies do not (Wilkins \& Zimmer, 1983a; Wilkins, 1984). On the other hand, there is both general and lease-specific evidence that users in aggregate (i.e., the stock market) are not misled by such presentational issues. In particular, there is quite strong evidence for both the UK (Beattie, Goodacre \& Thomson, 2000b) and the US (Ely, 1995; Imhoff, Lipe \& Wright, 1993) that the market already incorporates footnote operating lease disclosures in its assessment of equity risk. ${ }^{3}$ Further, there is evidence that, at least some, investment analysts and credit rating agencies recast financial statements by calculating the assets and liabilities implicit in off-balance sheet operating leases (e.g., DKB, 1998).

The general evidence that markets are informationally efficient suggests that any changes in reported performance resulting from the accounting changes are probably already impounded in stock market prices. However, the evidence that individual users (e.g., banklenders, investment analysts) may not be informationally efficient suggests that company capital-raising may be affected by the proposed accounting changes. Further, there is strong evidence that company managers do not believe that users, in aggregate or individually, process information efficiently (e.g. Mayer-Sommer, 1979; Abdel-khalik, 1981; Taylor \& Turley, 1985; Beattie, Goodacre \& Thomson, 2001b). This suggests that managers' decisions will be affected by the expected change in performance measures if all leases are 
required to be recognised on lessees' balance sheets, as a result of information inductance (Prakash \& Rappaport, 1977). ${ }^{4}$

Several prior studies have investigated the effect of lease capitalisation on ratio performance measures. In an early study, Nelson (1963) examined the impact on the debt-equity ratio of eleven US companies and found a significant change in the rankings of the companies after capitalisation. In the UK, Ashton (1985) estimated the effect of finance lease capitalisation on six ratios for 23 companies and found that only the gearing ratio would be affected significantly and that correlations between pre- and post-capitalisation ratios were high. However, his conclusion that inter-firm comparisons of performance would not be affected significantly by capitalisation may be subject to sample selection bias. ILW (1991) developed a method for the constructive capitalisation of operating leases and used this to estimate the impact of capitalisation on two ratios (return on assets and debt to equity) for 14 US companies (seven matched pairs, selected to represent high and low operating lease use). They found material differences in the ratios for both 'high' and 'low' lessees. In a subsequent paper (Imhoff, Lipe \& Wright, 1997), they explored income effects of operating lease capitalisation and indicate that the effects can be both substantial and unpredictable in direction. The retail investment analyst team at Dresdner Kleinwort Benson produced a research report highlighting the high level of gearing that would result from capitalising operating leases (DKB, 1998). This was based on a detailed study of 27 large UK general retail companies and showed that 'net debt would be in excess of $100 \%$ of equity market capitalisation in many cases, .... exposing shareholders to extremely volatile returns'. None of these studies directly investigate potential economic consequences of capitalisation, but the results allow such consequences to be inferred.

While these five studies are all based on small samples, BEG (1998) used a large random sample of 232 UK listed companies to estimate the potential impact of capitalising lease contracts currently classified as operating leases; they also made the link between impact and economic consequences. For 1994, they found that the average operating lease liability was $£ 51 \mathrm{~m}$, split between $£ 8 \mathrm{~m}$ short-term and $£ 43 \mathrm{~m}$ long-term, with the latter representing approximately $39 \%$ of on-balance sheet long-term debt, on average. There was a wide variation across different sectors ranging between 14\% (general industrial) and 69\% (services) of long-term debt, reflecting the variation in the use of operating lease finance. The $£ 43 \mathrm{~m}$ operating lease liability compared with an average reported liability for finance leases of $£ 4 \mathrm{~m}$, implying that operating leases were 13 times as important as finance leases. They also found that performance measures such as profit margin and gearing would be significantly affected by operating lease capitalisation. On average, operating profit margin increased from $8.7 \%$ to $9.8 \%$ and there was a dramatic increase in the gearing ratio (net debt to equity) from $20 \%$ to $72 \%$ for the sample as a whole and from $24 \%$ for $141 \%$ in the services sector. Further, the relative ranking of companies changed markedly both within and across different sectors. They concluded that 'significant changes in the magnitude of key accounting ratios and a major shift in company performance rankings suggest that interested parties' decisions and company cash flows are likely to be affected' by a policy change requiring operating lease capitalisation.

Each of the two approaches to ex ante assessment of likely economic consequences offers unique insights, though each also has its own inherent limitations. For this reason, the triangulation of results, where relevant, is to be recommended. A greater understanding of the potential impact of accounting change can be achieved by adopting both approaches and assessing the consistency of predictions. The present study based on the second approach complements the survey method adopted recently by Beattie et al. (2001a). Prior research 
suggests that indebtedness levels and performance measures in the retail sector are likely to be significantly affected if the G4+1 proposals are adopted as an accounting standard. The present study investigates whether the empirical evidence for a large sample of both small and large UK retail companies is consistent with these expectations.

\section{METHODS}

\section{Sample selection and data}

A list of food retail and general retail companies was extracted from Datastream and crosschecked to FT Sequencer database and yielded 106 companies. Of these, data could not be found for four companies leaving a total of 102 for further analysis. ${ }^{5}$ Basic data on sales, profits, assets and liabilities were extracted from Datastream for the period 1994 to 1999. Operating lease data is not available in computerised databases at a level of sufficient detail for the constructive capitalisation process. Thus all operating lease data were extracted manually from company microfiches, obtained from the Registrar of Companies, or from hard-copy published accounts. Data on finance leases were also collected in this way for consistency and to improve reliability.

\section{Impact of capitalisation on key accounting ratios}

To facilitate comparison with prior studies, the potential impact of capitalisation on nine key performance ratios was investigated. These ratios were an operating margin, three return on capital measures, asset turnover, income gearing and three capital gearing measures. Definitions of the measures are given in Table 1 together with the effect of operating lease capitalisation on each ratio.

\section{$<$ TABLE 1 here $>$}

In some contexts performance is judged against an absolute benchmark. For example, loan covenant restrictions may focus on a maximum gearing level or a minimum level of interest cover (or both). Executive compensation schemes may, in part, be based on achieving a particular level of profitability (e.g. return on assets, or return on equity). Consequently, changes in the actual performance measures are important so the differences between preand post-capitalisation ratios are investigated here.

In other decision contexts, such as investment decisions made by investors, the relative performance of companies may be more relevant (i.e. company rankings). The impact of operating lease capitalisation on relative performance is assessed by measuring the correlation between pre- and post-capitalisation ratios; both Spearman rank and Pearson correlation coefficients are reported and discussed.

\section{Operating lease capitalisation procedure}

The rights to use assets acquired under operating lease contracts are not currently recognised on the balance sheet of UK companies; rather, aggregate information about such contracts is disclosed by way of a note to the financial statements. The information disclosed is a schedule of next year's operating lease payments analysed by asset category (i.e. 'land and buildings' and 'other') and by lease expiry date (i.e. leases expiring within one year, between one and five years, and after five years). 
Estimation of the present value of the unrecorded lease liability requires assumptions to be made regarding the appropriate interest rate and the average remaining lease life. Estimation of the present value of the unrecorded lease asset requires further assumptions to be made regarding the average total lease life and the depreciation method. Finally, the impact of capitalisation on deferred tax requires an assumption to be made regarding the appropriate tax rate.

In the present study, the 'constructive capitalisation' procedure followed the basic method outlined by BEG (1998), which derived from ILW (1991). Effectively, the method incorporates company-specific assumptions in respect of the average remaining and total life of the company's lease portfolio, the lease asset/liability proportion and an effective tax rate. It also distinguishes between asset categories and lease expiry categories, with separate calculations of remaining lease life and asset/liability proportions performed for each. ${ }^{6}$ Depreciation on the lease asset is assumed to be charged on a straight-line basis over the life of the lease.

Company financial statements will be affected in several ways by the capitalisation of operating leases. The current standard on leases (SSAP21) details the accounting treatment for finance (capital) leases and this treatment has been assumed to apply to operating leases. On the balance sheet, fixed assets will increase by the capitalised leased asset, and liabilities will increase by the liability to make future lease payments, split between the current portion due within one year (current liability) and the longer-term portion. Shareholders' equity (retained profit) will be changed by the cumulative profit and loss effect of capitalisation and provisions will also be affected through adjustments to deferred tax.

In the profit and loss account the full operating lease rental (OLR) payment is presently charged against operating profit as a tax-deductible expense. On capitalisation of the leased asset, depreciation will be charged against operating profit and the interest element of the OLR will be included under interest charges. The impact is that operating profit will be higher (depreciation < OLR). Profit before tax will be lower in the early years of a lease, or lease portfolio, (depreciation + interest $>$ OLR) and higher in the later years as the interest element of OLR declines (depreciation + interest < OLR). Under current tax rules, the amount of tax paid will be unchanged. However, the tax charged in the profit and loss account will be lower in the early years of the lease portfolio, reflecting the lower profit before tax, and higher in the later years. The difference between tax paid and charged is accommodated by adjustments to deferred tax.

BEG (1998) describe a rationale for adopting particular remaining and total lease life estimates for each lease expiry category (<1year/2-5years/>5years) of each asset type (land and buildings/other). ${ }^{7}$ The same estimates are used in the present study. One of the key assumptions, for example, is that leases of 'land and buildings' within the ' $>5$ years' expiry category have 16 years remaining of a total 25 year lease life. ${ }^{8}$ The DKB study provides further support for the reasonableness of these assumptions. Given their analyst/broker relationship with companies, DKB were able to obtain estimates of average remaining lease life directly from companies. For 1999, these ranged between 5 and 48 years with four 'outlier' companies reporting remaining lives in excess of 40 years. Excluding these four outliers, the mean remaining lease life was 15 years (19 years including the outliers). Comparison of the median remaining life showed 13 in DKB against 14 in the present study, for companies common to both. The similarities between overall estimates of remaining lease life in the present study and those obtained by DKB suggest that the lease life estimates used here are reasonable. The differences observed suggest that the 
assumptions used here will tend to bias downwards the lease liabilities for the small number of companies having very long leases on their properties; i.e. the overall estimates will be slightly 'conservative'.

As the tax rate can vary considerably over time, an average tax rate for each company was calculated over the period 1994 to 1999. For companies reporting a loss in a particular year or with a negative tax charge (usually giving a negative tax rate), the tax rate was set to zero. To avoid distortions in the average tax rate, a small number ( 7 out of 483 firm-year observations) of outlier positive tax rates were set to $50 \%$.

There is considerable debate as to the appropriate interest rate to use in the discounting process. Various possibilities have been suggested including a single discount rate to be applied by all companies, a company-specific borrowing rate that will reflect the credit risk of the company, and a lease-specific rate (rate implied by the terms of the lease) that will reflect the lessor's risks as well as the credit risk of the lessee.

The G4+1 discussion paper argues that the major lessor risk is often 'residual value' risk, relating to the lessor's need to estimate residual value at the start of the lease contract. The current G4+1 proposals suggest that any guarantees, or other residual value arrangements, should be reflected in the 'fair value' of the guarantee that will be reported separately. In view of this, the appropriate discount rate for estimating the present value of minimum lease payments will be an 'estimate of the lessee's incremental borrowing rate for a loan of similar terms and with the same security as provided by the lease' (ASB, 1999, p.127). However, responses to the proposals in the discussion paper are mixed. While some commentators agree with the logic, others argue that this will reduce comparability between companies, since the same lease asset/liability will be valued differently in different companies. Further, it will lead to a situation in which riskier lessees will report a lower liability for the same lease contract because they will discount at a higher interest rate.

The main focus of the present study is to report average aggregate effects of leasing in the retail sector so a relatively simple approach is adopted. Land and buildings represent the major asset category for operating leases and these tend to be relatively long contracts, often of 15-50 years. The assumption implicit in the estimation of the present value of lease liabilities is that land and building contracts were, on average, of 25 years duration and started 9 years before the accounting period (i.e. remaining lease life $=16$ years). The average interest rate implied in 10-year UK government stock over the period 1984-1999 was $8.44 \%$, so a single risk-free discount rate of $8.5 \%$ is used for all companies. In view of the fall in interest rates over the 1990s this may lead to somewhat conservative estimates of operating lease liabilities and impacts. The sensitivity of the results to this interest rate assumption is tested by varying the discount rates by $\pm 1.5 \%$.

The impact of using discount rates adjusted for company-specific credit risk was also investigated. Based on a direct survey of companies, DKB (1998) estimated credit-risk premia for a selection of 27 general retail companies. As might be expected, there was a strong relationship between credit risk and company size. Consequently, the data in DKB was used to derive a simple linear model between credit risk premium and size; this model was then used to derive risk premia for the companies in the present study. ${ }^{9}$

A further issue relates to the treatment of rentals that rise in line with prices. The most common, and important, occurrence is in the upward-only rent review lease, typical of many commercial property leases in the UK. The G4+1 consensus is that the likely future 
price changes should be estimated at the start of the lease contract and incorporated in the calculation of the present value of minimum lease payments. This treatment is theoretically sound since a nominal interest rate (which incorporates the market's inflation expectations) is used to discount the cash flows. However, the ASB dissented from this view on the grounds that estimates of future price increases would be unreliable.

The main results of this paper are based on the ASB view, with no anticipation of future price increases. However, it is interesting to investigate the incremental impact of adopting the G4+1 approach. This is modelled by assuming that rent-reviews on 'land and buildings' leases occur at 5 year intervals. The basic lease life assumption for land and buildings leases that expire beyond year 5 is that there are 16 years remaining of a 25 year lease. Thus 9 years have already expired and a rent review will be due at year 10, in one year's time. Rentals are assumed to rise in line with general price inflation, estimated to be $3 \%$ per annum. ${ }^{10}$ This implies that rentals will rise from a current 100 in year 10 , to 115.9 for years $11-15$, to 134.4 for years $16-20$ and finally to 155.8 for the last five years of the contract. ${ }^{11}$

\section{RESULTS}

\section{Operating lease assets and liabilities}

Table 2 provides a summary of the estimated average values of operating lease assets and liabilities within the food retail and general retail sectors, and over all retail companies, for 1999. An indication of the scale of operating leases is provided by making comparisons with long-term (on-balance sheet) debt, total assets and finance lease liabilities. Estimates of average income effects are also presented.

\section{$<$ TABLE 2 here $>$}

The overall mean (median) level of operating lease liability in the retail sector for 1999 is estimated to be $£ 234 \mathrm{~m}$ ( $£ 60 \mathrm{~m}$ ), of which $£ 12 \mathrm{~m}$ is due within one year and $£ 222 \mathrm{~m}$ is due after more than one year. The large mean-median difference reflects the positively skewed size distribution of companies within the sector. Companies in the general retail sub-sector have slightly smaller operating lease liabilities (mean $=£ 222 \mathrm{~m}$ ) than those in food retailing (mean $=£ 287 \mathrm{~m})$. The scale of these off-balance sheet liabilities can be judged by comparison with the on-balance sheet long-term debt. On average, retailing companies have a mean debt level of $£ 67 \mathrm{~m}$ but there is a large difference between the two sub-sectors, with food retailers having $£ 173 \mathrm{~m}$ compared with $£ 41 \mathrm{~m}$ for general retailers. The ratio of the long-term element of operating lease liabilities to on-balance sheet long-term debt is 1.6 for food retailers, 5.1 for general retailers and 3.3 overall. These figures are based on the mean sector and sub-sector values of operating lease liability and debt. To appreciate the importance of operating leases at the individual company level, median ratios were estimated excluding those companies with zero long-term debt. The median ratios were 2.9, 9.1 and 6.6 for food, general and the sector overall. ${ }^{12}$ Thus, in the retail sector, and particularly the general retailing sub-sector, operating lease finance is significantly more important than long-term debt. This is of major potential importance in the assessment of financial risk.

The level of finance (capital) lease liabilities is relatively small in the retail sector with mean liabilities of $£ 10.8 \mathrm{~m}$ (food), $£ 5.4 \mathrm{~m}$ (general) and $£ 6.4 \mathrm{~m}$ (all); the median finance lease liabilities are very small (all less than $£ 0.1 \mathrm{~m}$ ). The relative unimportance of finance leases is clear from the operating lease/finance lease ratios of 27 (food), 41 (general) and 37 (all); i.e. 
operating lease liabilities are, on average, approximately 37 times the level of finance leases.

On the asset side, mean total operating leased assets are estimated to be $£ 182 \mathrm{~m}$, the major part of which is land and buildings $(£ 178 \mathrm{~m}, 98 \%)$ rather than plant and equipment $(2 \%)$. These off-balance sheet assets represent a major proportion of reported total assets with estimates, based on overall means, of $16 \%$ for the food sub-sector, $37 \%$ for general and $28 \%$ overall. The equivalent median figures based on individual company ratios are higher at $34 \%, 55 \%$ and $52 \%$ respectively. Thus, operating leased assets are extremely important in the retail sector, and their current exclusion from the balance sheet has the potential to distort return on asset type performance measures.

The effect of operating lease capitalisation on operating profit (EBIT) will be positive since expenses will include depreciation rather than the operating lease rental (and depreciation < OLR). The approximate effect in the retail sector is that the mean operating profit would increase by $14 \%$ (food), $30 \%$ (general) and $23 \%$ (all). The impact on net profit (profit after tax) depends on the stage reached in the life of the lease portfolio. In the early years, net profit is reduced (depreciation + interest $>$ OLR) and this is reversed in the later years of a lease contract (or portfolio). If investment in operating leased assets is growing (as in the retail sector) then companies will generally be in the 'early years' period. Based on this assumption, the reduction in mean net profit is estimated to be $4 \%$ (food), 9\% (general) and 7\% (all); median net profit reductions based on individual company data are similar. Thus, the average impact on net profit is relatively small, but the average does mask the fairly drastic effect that would be felt by some companies, notably those with very high levels of operating leases or those with low levels of reported profit.

\section{Impact of capitalisation on performance ratios}

There are several features of the data that cause difficulties in calculating or interpreting the performance ratios or changes therein. As a result, some companies had to be excluded from the analysis of ratios:

(a) Four companies had negative equity in their reported financial statements (i.e. prior to capitalisation of operating leases) leading to problems with equity-based and asset-based ratios. ${ }^{13}$ Excluding these companies totally from further analysis led to sample sizes of 18 (food), 80 (general) and 98 (all).

(b) Capitalisation of operating leases led to several additional companies having negative equity. These have been excluded only from the analysis of the three ratios specifically

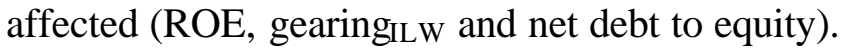

(c) Companies having zero interest in their reported financial statements are excluded from analysis of interest cover. This is necessary because it is not possible to calculate changes in interest cover since pre-capitalisation interest cover equals infinity.

Table 3 reports the results from assessing the impact of operating lease capitalisation on performance ratios in the retail sector for 1999. The notes at the foot of the table give full details of the numbers of companies excluded from analysis.

\section{$<$ TABLE 3 here >}

To reduce the impact of outlier observations, median rather than mean ratios are reported. The ratios are calculated pre-capitalisation based on figures in the published financial 
statements (termed pre in the table) and post-capitalisation. The difference between medians is also reported together with a two-tailed test of whether the samples are drawn from populations with the same medians and the same continuous distribution (the Wilcoxon signed ranks test). ${ }^{14}$ Two-tailed t-tests of mean differences were also carried out (but not reported here) and, except where noted, similar results were obtained.

For the general retail sub-sector, significant differences were observed for all nine ratios (at the $1 \%$ level). ${ }^{15}$ The median operating margin increased (from $8.1 \%$ to $11.5 \%$ ), ROA decreased, asset turnover decreased and the three gearing measures all increased; for example, net debt to equity increased from $17 \%$ to $157 \%$ after capitalisation of operating leases. For the three ratios with indeterminate directional expectations, ROE increased, ROCE decreased and interest cover decreased. For food retailers, five of the nine median ratios were significantly different (at the 1\% level), three of them (ROA, ROCE and interest cover) at the $5 \%$ significance level with just ROE not significant. ${ }^{16}$ For the sector as a whole, all ratios were significantly different following capitalisation of operating leases. Thus, a requirement to capitalise all operating leases would potentially have a major impact on ratio measures of operating performance. This could have important economic consequences in decision contexts where performance is judged against an absolute benchmark, such as loan covenant restrictions or executive compensation schemes.

In other decision contexts (such as investment decisions made by investors) the relative performance of companies is more relevant. The impact of operating lease capitalisation on relative performance is assessed by measuring the correlation between pre- and postcapitalisation ratios. Both Spearman rank and Pearson correlation coefficients are reported in Table 4. Broadly similar results are obtained for food and general retailers. The ratios can be split roughly into three groups on the basis of the strength of pre- and post-capitalisation correlations. A group of four ratios have 'moderate to high' positive correlations (above 0.8 on one or both measures); these are the three return on asset measures and the profit margin. A group of three ratios have 'low' positive correlations (between 0.6 and 0.8 , but statistically significantly greater than zero); i.e. asset turnover, interest cover and the

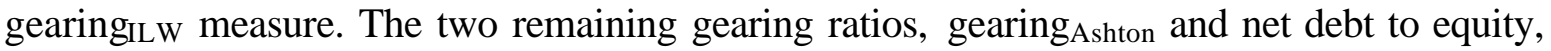
both have 'very low' correlations (less than 0.3 , statistically insignificantly different from zero $^{17}$ ). Thus, lease capitalisation will affect relative performance based on all nine ratios considered, but particularly on gearing measures.

$<$ TABLE 4 here >

\section{Comparison with other sectors in prior studies}

Table 5 provides a comparison between the balance sheet effects for retail companies and the overall (across all sectors) and services sector results reported by BEG (1998). The retail figures are based on those companies from the current sample that existed in 1994 (the last year and focus of the BEG study). Thus this sub-sample suffers from survivorship bias. However, comparisons between 'new' and 'continuing' retail companies (not reported here) show that 'continuing' companies have lower usage of operating leases than 'new' companies. So, in view of the directional difference observed, survivorship bias is likely to reduce the reported differences. Also, to avoid distortions due to different interest rates the retail figures are calculated using a 10\% discount rate, as applied by BEG.

$<$ TABLE 5 here $>$ 
The mean total operating lease liability within the retail sector companies in 1994 is estimated to be $£ 195 \mathrm{~m}, 1.9$ times higher than the services sector and 3.8 times higher than the overall level reported in BEG. The retail operating lease liability is 2.56 the level of onbalance sheet debt compared with 0.7 (services) and 0.39 (overall). A similar picture emerges for the operating lease asset, which for retail is $23 \%$ of total assets compared with $13 \%$ (services) and 6\% (overall). These figures confirm prior expectations that retailers are heavy users of lease finance, much heavier than most other sectors (as suggested in Beattie et al., 2000a).

A comparison between changes in performance ratios for retail companies and those reported in two prior studies (BEG, 1998 and ILW, 1991) is given in Table 6. For closer consistency with the prior studies, the comparisons are based on mean ratios (rather than medians) derived from 1994 data. ${ }^{18}$ While formal cross-study significance tests cannot be applied, the impact of operating lease capitalisation in the retail sector is clearly much greater than reported in these prior studies. For example, the changes in gearing ratios for retailers are between 4.7 and 8.6 times greater than the all-sector changes in the UK (BEG, 1998) and the change in gearing ILW $_{\text {is }} 2.5$ times greater than the average change reported for US companies (ILW, 1991). ${ }^{19}$ These observations are consistent with the very heavy use of operating leases in the retail sector illustrated above.

$<$ TABLE 6 here >

\section{Sensitivity analysis}

To test the inter-temporal stability of the findings, the basic analysis reported in Tables 2 through 4 was repeated for the four years 1994 through 1998 on several alternative bases. For illustrative purposes, the figures for all retailers based on a constant discount rate of $8.5 \%$ will be used. Across the retail sector as a whole, the estimated mean total operating lease liability varied between $£ 213 \mathrm{~m}$ (1994) and £229m (1997) compared with the £234m reported for 1999 in Table 2. The ratio of the long-term element of the operating lease liability to long-term debt ranged from 2.94 (1994) to 3.91 (1997) compared with 3.32 in 1999 (Table 2). Across all years and all nine ratios for both sub-sectors and all retailers, the changes in median performance ratios following capitalisation were of the same sign, of similar magnitude and were all significantly different from zero. ${ }^{20}$ For example, the differences in net debt to equity varied between $+102 \%$ (1996) and $+152 \%$ (1997) compared with $138 \%$ in 1999 (Table 3). With minor exceptions, the pattern of correlations each year was consistent with that illustrated for 1999 in Table 4. Thus, the impact of operating lease capitalisation seems to be stable over the time period covered here.

The sensitivity of the results to key assumptions was investigated using 1999 data. First, the base assumption of a common interest rate of $8.5 \%$ was varied by $\pm 1.5 \%$. Second, the base estimates for remaining (RL) and total lease (TL) lives were changed to more extreme, but still plausible, estimates. This only really affects leases in the category that expire after more than five years. One set of estimates places leases at an earlier stage in a long lease; for land and buildings $R L=22$ years, $T L=30$ years, for other assets $R L=9$ years, $T L=12$ years. The other set places leases at a later stage in a short lease; for land and buildings RL $=10$ years, $\mathrm{TL}=20$ years, for other assets $\mathrm{RL}=5$ years, $\mathrm{TL}=8$ years. $^{21}$

For all four scenarios, all ratio differences were of similar size, in the same direction and had identical significance levels, with one or two minor exceptions caused by extreme outliers. These exceptions were for the changes to base estimate lease lives and just three 
ratios. The change in median ratio for ROCE in food retailers in the later stage/short lease scenario was of similar size, in the same direction but ceased to be significant at the 5\% level. No other median change was significantly affected. For changes in mean ratios, the ROE ratio was affected by extreme outliers and changed sign for general retailers in the early stage/long lease scenario. In the later stage/short lease scenario the gearing ILW ratio ceased to be significant and the net debt to equity ratio was only significant at the $5 \%$ level, both driven by extreme outliers (e.g. Harveys Furnishing had a post-capitalisation net debt to equity ratio of 20,298\%!). In all cases, removal of the outliers led to results consistent with the original assumptions employed. Correlations between pre- and post-capitalisation ratios were all of similar magnitude to those observed for the original assumptions. In view of the minor changes, detailed results are not reported.

Further confidence in the estimation process can be gained by comparing results from the present study with those obtained by DKB (1998). 23 companies are common to both studies based on 1998 year-ends. The mean estimated lease liability in the present study was 8.4\% lower than DKB estimated for these same companies. However, the correlation between estimates was very strong (Pearson $=0.96$, Spearman $=0.98$ ). The measure of agreement between the estimates in the present study, based only on publicly-available data, and those of DKB based on semi-privileged information is very encouraging.

One of the sample companies, WH Smith plc, voluntarily disclosed additional information about its operating lease liability in its financial statements for the year ending 31 August 1999. In particular, it reported that its total liability is $£ 700 \mathrm{~m}$ after discounting its future minimum operating lease commitments at a before tax weighted average cost of capital of $10.4 \%$. In the present study, using the standard common risk-free discount rate of $8.5 \%$, the estimated liability based solely on the SSAP21 disclosures is $£ 832 \mathrm{~m}$. However, a large proportion of the difference relates to the application of an alternative principle in choosing the discount rate. Using the same discount rate in the present study would have given an estimated liability of $£ 750 \mathrm{~m}$, just $7 \%$ higher than the company disclosed figure.

The sensitivity analysis suggests that the results of this study are robust to the key assumptions incorporated in the operating lease capitalisation procedure. Comparisons of estimates from the present study with those based on more detailed knowledge of individual company circumstances further increases confidence in the reasonableness of the procedures adopted herein.

\section{Company-specific interest rates}

As the main focus of the present study is to report average aggregate effects of leasing in the retail sector, a single risk-free discount rate of $8.5 \%$ is used. However, the G4+1 recommendation is that the appropriate discount rate is an 'estimate of the lessee's incremental borrowing rate for a loan of similar terms and with the same security as provided by the lease' (ASB, 1999, p.127). The impact of using such lessee-specific discount rates adjusted for company credit risk was also investigated. Based on a simple linear model between credit risk premium and size, credit-risk premia were estimated for the companies in the present study, as outlined earlier. From this model the estimated credit risk premia for the current study averaged $1.9 \%$ and ranged between $0.66 \%$ (Tesco) and $2.92 \%$ (Bakery Services) in food retailing, and between $0.66 \%$ (Marks and Spencer) and $3.02 \%$ (Blakes Clothing) in general retailing. 
As expected when applying a higher discount rate, the estimated total operating lease liability and asset are lower: the mean (median) liability and asset reduced by $5.6 \%(10.6 \%)$, $7.1 \%(11.7 \%)$ and $6.7 \%(11.7 \%)$ for food, general and all retailers, respectively. Profit and loss account effects increased slightly as a result of the higher interest charge. For 'all retailers', operating profit increased by $24.5 \%$ compared with an increase of $23.2 \%$ when using a single risk-free rate for all companies, and after-tax profit fell by $8.0 \%$ compared with a fall of $7.3 \%$. The impact on performance ratios was relatively small, but the median differences were almost entirely statistically significant. Profit margin, ROA, ROCE and asset turnover all improved (increased), the three gearing ratios improved (decreased) but $\mathrm{ROE}$ and interest cover both deteriorated (decreased). The changes in median ratios for 'all retailers' averaged $5.1 \%$ of the level of the original (risk-free) ratio, and ranged between $1.7 \%$ for ROA (a decrease from $16.13 \%$ to $15.14 \%$ ) and $9.5 \%$ for net debt to equity (a fall from $153.6 \%$ to $139.0 \%$ ). These results suggest that performance, measured against an absolute benchmark, would generally look better if credit-risk adjusted rather than risk-free discount rates are used. This is mainly a function of using a higher discount rate, which reduces asset and liability estimates. The impact will be higher for companies with a lower credit rating; i.e. for riskier, often smaller, companies.

Also important is the impact of using credit-risk adjusted discount rates on relative performance; i.e., does the use of a lessee-specific discount change the performance ranking of companies? This can be assessed by considering the correlation between a company's ranking on each performance measure for the two discount rates. The Spearman rank correlation coefficients were all close to 1 . For food retailers they ranged between 0.975 and 1.0 and for general retailers between 0.993 and 1.0. Thus relative performance in the retail sector would not be affected by the choice between the two discount rates.

Overall, the use of a credit-risk adjusted rather than a risk-free discount rate would reduce slightly the impact of lease capitalisation. It would have very little impact on intra-sector performance ranking. This is useful information for standard-setters in making the choice between the two. However, this study focuses on only one sector in which there is generally a high level of lease usage. The use of a risk-free discount rate would increase the contrast between sectors/companies with high and low lease usage. It also avoids the 'anomaly' that identical assets (and liabilities) would be valued differently by different companies, with riskier companies reporting lower liabilities. The use of a single discount rate across all companies has the further advantage of simplicity, consistent with the adage that it is better to be approximately right than precisely wrong'.

\section{G4+1 proposal to anticipate future rental increases}

The modelling of the incremental effect of anticipating future increases in lease rentals, as proposed in the discussion paper by $\mathrm{G} 4+1$, provides useful evidence for both company managers and standard-setters. Post-capitalisation, the overall mean operating lease liability would rise $25.1 \%$ from $£ 234.5 \mathrm{~m}$ (Table 2) to $£ 293.4 \mathrm{~m}$, and would be 4.3 times the level of on-balance sheet debt (up from 3.3 in Table 2). The operating lease asset would represent $35 \%$ of on-balance sheet assets (up from $28 \%$ in Table 2).

The anticipated positive impact on operating profit would be slightly lower at $+19.2 \%$ (from $+23.2 \%$ ) as a result of higher depreciation on the leased asset. The larger operating lease liability implies that a larger part of the current operating lease rental relates to interest (rather than capital repayment). This leads to a much more pronounced change in profit after tax, which would fall by $-19.1 \%$ (compared with $-7.3 \%$ in Table 2 ), reflecting the 
increased interest charge on top of the higher depreciation. Thus, the G4+1 proposal would have a much larger negative impact on reported profit after tax in the earlier stages of a lease portfolio (assumed in the present paper). However, this would reverse in the later stages when a much smaller impact on profit would be experienced (see Ringer \& Unerman, 2000 , for a neat graphical illustration of this effect).

Consistent with the larger operating lease asset and liability, seven of the nine ratios would suffer a greater impact if future rental increases were recognised. For example, postcapitalisation ROCE would fall even further to $12.4 \%$ (15.1\% in Table 2) and net debt to equity would rise even higher to $186 \%$ (from $154 \%$ in Table 2). The first of the two ratios with reduced impacts is operating profit margin (as explained above) with a median of $10.1 \%$ (10.7\% in Table 2), but the change from pre-capitalisation level is still statistically significant (1\% level). The second ratio, ROE would have a median value of similar magnitude $(13.5 \%)$ to its pre-capitalisation level. Intra-sector correlations would increase slightly for profit margin and ROE but would decline for the other seven ratios, the results suggesting a moderate change in companies' rankings.

Overall, adoption of the G4+1 proposals concerning lease rentals that rise in line with prices would exacerbate the already large impact of operating lease capitalisation in the retail sector. Asset and liability levels would increase more, than under the ASB's preferred approach and, in particular, profit after tax levels would suffer quite seriously in the earlier stages of the life of a lease portfolio. As a result, performance ratios and company rankings would also deteriorate.

\section{Managers' response to lease capitalisation}

A major assumption in the paper thus far, somewhat unrealistic in the light of prior evidence, is that company management will not take any steps to mitigate the effect of capitalisation. Rather extremely, they might change their asset financing policies away from leasing, but this may not be possible, for example in obtaining access to 'land and buildings' assets. Alternatively, they might seek to modify lease contract terms to minimise the impact of capitalisation as illustrated by their switch from finance to operating lease contracts in response to the introduction of SSAP21. Based on the current G4+1 proposals, a possible route focuses on the treatment of renewable leases. A lease may be written for a fairly short primary rental period with an option to renew the lease. Under the G4+1 proposals, the exercise of renewal options 'should not generally be anticipated' except where the fixed non-cancellable term is clearly unrepresentative of the period that the lessee is compelled to use the property (ASB, 1999, pp. 90-91). Thus, one way to mitigate the impact of lease capitalisation would be to use shorter primary lease periods (much shorter than current practice on 'land and buildings' contracts) with options to renew for further short periods. ${ }^{22}$

Obviously, this would not suit all circumstances. However, it is consistent with the trend towards lessees seeking shorter leases for purely commercial reasons, mainly reflecting lessees' need for greater flexibility in choosing and changing locations of retail outlets, for example (Nelson, 1999; BPF/IPD, 1999). These renewable short contracts are likely to shift risks from lessees to lessors since, for example, the lessor will now bear the risk that the lessee will not exercise the option to renew. This is most likely to happen when the attractiveness of the asset has reduced for some reason. When this is a general 'decline' in the future worth of the asset, rather than lessee-specific, then a significant cost (loss of value, difficulty in obtaining a new lessee or disposing of the asset) will be borne by the lessor. This risk shift will be of concern to lessors, some of whom will see it as a threat 
while others may recognise an opportunity for increasing returns to compensate for the extra risk.

A new set of calculations was undertaken to obtain a preliminary 'feel' for the change in impact if all company managers were to adopt this approach. For this, a simple but fairly radical assumption was made that all lease contracts (i.e., both 'other' and 'land and buildings' categories) would have a maximum term (TL) of 5 years. After an initial phase the average remaining life (RL) for these contracts would settle at about 3 years. A second assumption implicit in the calculations is that the value of the renewal option will be small and so can be ignored. For simplicity, any increase in lease rental required to compensate for the lessor taking on additional residual value risk is also ignored; this may impart a downward bias to the estimation of lessees' operating lease assets and liabilities. The overall impact on reported lease assets and liabilities based on 1999 data is summarised in Table 7 , and the consequent effect on performance ratios in Table 8.

$<$ TABLE 7 here >

Notwithstanding the radical nature of the assumption, operating lease assets and liabilities would remain a substantial feature on retail companies' balance sheets. The mean total operating lease liability estimates are $£ 94 \mathrm{~m}$ (food retailers), $£ 77 \mathrm{~m}$ (general retailers) and $£ 80 \mathrm{~m}$ (all); the long-term element of these liabilities represents $37 \%, 128 \%$ and $82 \%$ of onbalance sheet debt, respectively. Overall, reported operating lease assets would represent approximately $11 \%$ of total assets. The impact on profit would also be slightly reduced but, across the retail sector overall, operating profit would still increase by about $9 \%$ and profit after tax would decrease by about $4 \%$; the impact on general retailers would continue to be slightly greater than on food retailers.

As expected, the size of the impact on performance ratios is also reduced, but the pattern and (statistical) significance of the median changes is almost identical. The one exception is the small reductions in median ROE, which are statistically significant but the size of the changes suggests low economic significance. ${ }^{23}$ Correlations between pre- and postcapitalisation ratios are higher than those reported in Table 4 and range between 0.22 and almost 1 . The margin, return and asset turnover ratios are now mainly above 0.9 , but interest cover and two of the three gearing ratios remain 'low'. For example, the Spearman rank correlation coefficient for the net debt to equity ratio is 0.53 (food) and 0.49 (general), and for gearing $\mathrm{Ashton}_{\text {is }} 0.49$ (food) and 0.33 (general).

\section{$<$ TABLE 8 here $>$}

The situation of maximum 5-year lease contracts modelled here may not be appropriate for some contracts. However, other 'opportunities' for mitigating the impact will be available (e.g. the use of contingent rental contracts?). The above results suggest that, in the retail sector, lease capitalisation will probably have a fairly major impact on published financial statements and on performance ratios, even if company managers take steps to minimise the impact.

\section{SUMMARY AND CONCLUSIONS}

The rights to use assets acquired under operating lease contracts are not currently recognised on the balance sheet of UK companies; rather, aggregate information about such contracts is disclosed by way of a note to the financial statements. Two G4+1 discussion papers have 
addressed the issue of off-balance sheet leases and the more recent of these, Leases: Implementation of a New Approach (ASB, 1999), proposes that all leases should be recognised on the balance sheet. The main objective of the present research is to assess the potential economic consequences of the proposed changes to lease accounting by examining all of the companies in the UK Retail sector over the 1994-99 period. Unrecorded operating lease assets and liabilities were estimated using a 'constructive capitalisation' procedure. The possible magnitude of the impact of lease capitalisation was assessed by examining the effect on nine key accounting ratios that are used in decision-making and in financial contracts.

Operating lease finance was confirmed as a major source of finance in the retail sector. Indeed, the level of the off-balance sheet operating lease liability is much higher (3.3 times higher, overall) than the level of on-balance sheet debt. Thus, operating lease finance is significantly more important than long-term debt, an observation that is of major potential importance for users' assessment of financial risk. By contrast, finance leases are essentially immaterial, as indicated by the observation that operating lease liabilities are, on average, approximately 37 times the level of finance leases.

Operating lease assets represent a major proportion of reported total assets with estimates, based on overall means, of $16 \%$ for the food sub-sector, $37 \%$ for general and $28 \%$ overall. The majority of these assets relate to land and buildings ( $98 \%$ by value) rather than plant and equipment (2\%). The current exclusion of these assets from the balance sheet has the potential to distort return on asset type performance measures.

The estimated impact on operating profit is an increase of about $23 \%$, on average, since the depreciation charged on leased assets will be less than the operating lease rentals. Profit after tax is expected to reduce by about $7 \%$. However, this fairly small average impact masks the fairly drastic effect that would be felt by some companies, notably those with very high levels of operating leases or with low levels of reported profit.

Capitalisation of operating leases would potentially have a major impact on all nine ratio measures of operating performance. This could have important economic consequences in decision contexts where performance is judged against an absolute benchmark, such as loan covenant restrictions or executive compensation schemes. In other decision contexts (such as investment decisions made by investors) the relative performance of companies is more relevant. The results show that the ranking of companies changes markedly for asset turnover, interest cover and the three capital-based gearing measures, and especially for general retailers. Results were shown to be robust with respect to key assumptions of the capitalisation method (i.e. discount rates, lease life estimates) and also over time.

Comparison with the earlier cross-sectoral study of BEG (1998) confirmed that retail companies are very heavy users of operating leases, with an overall mean operating lease liability 3.8 times higher than reported by BEG. The ratio of operating lease liability to onbalance sheet long-term debt was over six times larger in the retail sector. Given this, the much greater impact on performance ratios in the retail sector is not surprising, but this does not diminish the amazing scale of the impact. For example, the major increase in net debt to equity of $260 \%$ reported by BEG is swamped by the staggering $2246 \%$ increase in the retail sector.

The G4+1 discussion paper suggests using credit-risk adjusted discount rates for individual companies rather than a single risk-free interest rate. The overall effect of this would be to 
lessen slightly the impact of capitalisation, as a result of using a higher discount rate to compute the present value of minimum lease payments. However, it would have little impact on intra-sector ranking of company performance. Inter-sectoral differences are not explored in this paper, but it is likely that using a higher discount rate would reduce the differences between sectors with high and low lease usage.

The ASB dissented with one of the G4+1 proposals concerning the treatment of lease rentals that rise in line with prices. In particular, G4+1 suggested that the increase in future rentals should be estimated at the start of the lease contract and incorporated into the valuation of the operating lease asset and liability. The recognition of future rental increases was modelled and the incremental effect was found to be quite important. Reported operating lease assets/liabilities would be substantially higher (by about 25\%) with commensurate changes in most performance ratios, including gearing levels. In the early stages of a lease portfolio, profit after tax would significantly decline. The size of these impacts, coupled with the uncertainties involved in estimating future rental increases identified by the ASB, suggest that company managers are likely to resist this G4+1 proposal quite vigorously.

One method by which managers might seek to minimise the impact of capitalisation is the use of renewable short lease contracts. The effect of one particular type of contract (i.e. a 'rolling five year' lease contract) for 'land and buildings' was also assessed. While this reduces the level of operating lease assets and liabilities, very significant amounts would still be reported on-balance sheet. The mean operating lease liability for the sector would still represent $82 \%$ of on-balance sheet long-term debt. All performance ratios continue to be significantly affected. For example, net debt to equity would increase from $16 \%$ to $57 \%$, a percentage change of $260 \%$, the same average change that BEG (1998) reported across all sectors in the absence of any management attempt at mitigation.

These findings contribute to the assessment of the economic consequences of a policy change requiring operating lease capitalisation. Prior research suggests that individual users of financial statements are not efficient information processors, and also that company managers do not believe that users, even in aggregate (e.g. the stock market) are efficient processors. Consequently, the significant changes in the magnitude of key accounting ratios and the major shift in company performance rankings suggest that interested parties' (especially company managers') economic decisions are likely to be affected. The level of operating lease use in the retail sector is very high, on average. The results of modelling the impact of adopting renewable short-term lease contracts suggest that company managers, and their advisers, may find it difficult to avoid a significant impact on the balance sheet and on key performance ratios.

The results also have implications for researchers concerned with investigating company financing and capital structure decisions. Non-capitalised operating lease finance is an important source of finance and one whose usage varies across different companies and sectors. This implies that studies of capital structure that ignore operating leases can only provide a partial portrayal of corporate finance practice. 


\section{NOTES}

1 These figures are derived from data reported by Beattie, Edwards \& Goodacre $(1998)$ and Beattie, Goodacre
$\&$ Thompson $(2000 \mathrm{a})$. The mean total lease finance was estimated at $£ 54.6 \mathrm{~m}(£ 3.8 \mathrm{~m}$ finance leases, $£ 50.8 \mathrm{~m}$
operating leases) and so gives a total lease liability of about $£ 71$ billion $(£ 54.6 \times 1300)$ for the total of
approximately 1300 companies in the Datastream UKQI list for 1994 . Total lease finance to long-term debt $=$
$51 \%(£ 54.6 \mathrm{~m} / £ 108.1 \mathrm{~m})$. The ratios of total leases to total assets $\left(L R_{C}\right)$ and net fixed assets to total assets
(faprop), after adjustment for operating lease capitalisation in the former ratio, allow the calculation of $28 \%$
for leases to net fixed assets.

${ }^{2}$ Beattie et al. (2000a) report that, across all sectors in 1994, 'land and buildings' represented over $80 \%$ of the total value of operating leased assets.

${ }^{3}$ By contrast, Gallery \& Imhoff (1998) found no evidence that Australian stock market investors incorporate footnote operating lease disclosures in their assessment of equity risk.

${ }^{4}$ For example, company managers appear to have reacted in this way to a requirement to report inflationadjusted income numbers in the US (Odaiyappa and Nainar, 1992).

5 The four with missing data were Kleeneze, Magic Moments Internet, Partners Holdings and Oriflame International; the latter is registered in Luxemburg. Of the 102 analysed, two were registered in the Channel Islands (Flying Flowers and Le Riche Group) and one in Northern Ireland (Hampden Group).

6 An alternative approach to estimating the operating lease asset value has been adopted in the present paper (see BEG, 1998, footnote 9, p. 243,). The asset $\left(\mathrm{PV}_{\mathrm{A}}\right)$ and liability $\left(\mathrm{PV}_{\mathrm{L}}\right)$ values are related as follows: $\mathrm{PV}_{\mathrm{A}} / \mathrm{PV} \mathrm{L}_{\mathrm{L}}=\left(\mathrm{RL} \times \mathrm{PVAF} \mathrm{F}_{\mathrm{i}, \mathrm{TL}}\right) /\left(\mathrm{TL} \times \mathrm{PVAF} \mathrm{F}_{\mathrm{i}, \mathrm{RL}}\right)$, where $\mathrm{RL}$ and $\mathrm{TL}$ are remaining and total lease lives, and $\mathrm{PVAF}_{\mathrm{i}, \mathrm{n}}$ is the present value of an annuity for $\mathrm{n}$ years discounted at $\mathrm{i} \%$ (BEG, 1998, equation 8, p. 243). In the BEG paper, the $\mathrm{PV}_{\mathrm{A}} / \mathrm{PV}_{\mathrm{L}}$ proportion was based on the historically weighted average RL and TL. In the present paper, the $\mathrm{PV}_{\mathrm{A}} / \mathrm{PV}_{\mathrm{L}}$ proportion is estimated for each expiry category, rather than using the overall average remaining and total lease lives. This approach reflects the current year position and is more appropriate for companies in which the historic average differs from the current balance between expiry categories. While this changes the estimated asset value for individual companies, as BEG report, the overall results are robust with respect to these alternatives.

${ }^{7}$ The remaining lease life estimates for the three expiry categories for 'land and buildings' are 1 year $(<1$ year expiry), 3 years ( $1-5$ years expiry) and 16 years ( $>5$ years expiry); the equivalent total lease life estimates are 1,3 and 25 years respectively. For the 'other' category of assets, the remaining (total) lease life estimates are 1 (1), 3 (5) and 7 (10) years for the three expiry categories.

${ }^{8}$ The British Property Federation/Investment Property Databank Annual Lease Review (BPF/IPD, 1999) also provides support for these assumptions. The average rent-weighted lease length of new leases over the period 1990-93 was 22.8 years. In more recent years, the lease life trend has been downwards; the average for new leases has fallen to 19.3, 18.5 and 16.4 years for 1994-5, 1996-7 and 1998-9 respectively. This downward trend will have some impact on the average life of 'land and buildings' leases for the retail companies in the study. However, these data are for new leases and, for many companies, a large proportion of their lease portfolio will have originated prior to the recent period in which lease lives have been falling. This may not be true for new companies in the sector and so there may be an element of upward bias in our estimates for new companies.

${ }^{9}$ The model was estimated using OLS based on credit premium data on page 34 in DKB (1998). The derived model was: premium $(\%)=2.902-0.2395 \ln ($ market capitalisation in $£ \mathrm{~m}) ; \mathrm{R}^{2}=81 \%$. From this model the estimated credit risk premia for the current study ranged between $0.66 \%$ (Tesco) and 2.92\% (Bakery Services) in food retailing, and between $0.66 \%$ (Marks and Spencer) and 3.02\% (Blakes Clothing) in general retailing.

${ }^{10}$ In practice, the increase in rentals would depend on various factors such as general and local economic conditions at the time of the rent review, the exact site and nature of the property, demand and supply factors, and ultimately on the relative bargaining power of landlord and tenant. Consequently, the estimates of rental increases would probably be different for each property and would also be subject to considerable uncertainty; these issues have contributed to the ASB's dissension. 
11 The overall effect of such rental increases is to increase the operating lease liability at the end of year 9 by $26.9 \%$.

12 There were 3, 22 and 25 companies with zero long-term debt in food, general and the sector overall. Including these companies increased the observed median ratios to 3.3, 39.6 and 29.2 respectively.

${ }^{13}$ For example, a loss-making company with negative equity produces a positive ROE ratio. A more profitable company with negative equity produces a more negative ROE, so ROE is not a continuous measure for companies having negative equity. Similar issues arise with equity-based gearing measures. Asset-based

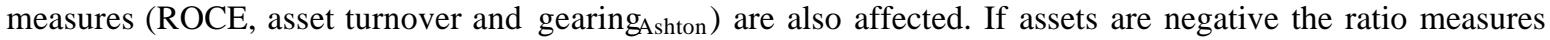
are again not continuous, and even if positive the reduced asset size can lead to distorted ratios.

14 The use of a non-parametric test is more suitable given the non-normal distribution of many ratios (Barnes, 1987). Despite the existence of uni-directional expectations for six of the ratios, for consistency two tailedtests were used throughout, leading to conservative reported significance levels for these ratios.

15 Several extreme outliers (defined as the quartiles $\pm 10 \times$ inter-quartile range) were identified in the ratio differences for interest cover ( 9 outliers) and the three ratios involving equity: ROE ( 9 outliers); gearing ILW $_{\text {( }} 3$ outliers) and net debt to equity ( 3 outliers). Excluding these extreme outliers, the mean differences between pre- and post-capitalisation ratios had identical signs and two-tailed t-stat significance to those reported for median differences. Including outliers, identical signs and significance were observed for seven ratios, but the mean difference for ROE was not significant and for interest cover was significant at the 5\%, rather than $1 \%$, level.

${ }^{16}$ Mean differences were not statistically different for ROE, ROA, ROCE or interest cover, even after removal of the 2 extreme outliers for the interest cover ratio.

17 The one exception here is the Pearson correlation coefficient for the net debt to equity gearing measure in the food retailing sub-sector; the coefficient is 0.57 and significantly above zero (at the $5 \%$ level).

18 Extreme outlier companies (discussed in footnotes 6 and 7 above) were excluded from the mean ratio calculations from which this table is derived.

19 The fourteen companies in the ILW (1991) study include 4 food retailers, 4 general retailers, 4 fast-food restaurants and 2 airline companies, paired on the basis of being either a 'high lessee' or 'low lessee' company. Data was derived from accounts for the 1987 fiscal year.

20 There was just one exception. While the difference in the ROE ratio for general retailers for 1994 was of the same sign and similar magnitude to the other years, it was not statistically significant.

21 The early stage/long lease combination tends to increase operating lease asset and liability and increase interest charge, thereby reducing profit; the opposite is true for the later stage/short lease combination.

${ }^{22}$ A similar effect can be achieved using break clauses. These can be used to give the lessee an option to exit the lease contract at various stages during the contract (e.g. every five years?).

23 The balance between profit impact (numerator) and equity impact (denominator) is now tipped towards a greater negative change in the numerator, leading to a reduction in median ROE. Mean changes in ROE for general retailers are again affected by extreme outliers. After removal of these, the mean change for general retailers is $-0.20 \%$ (statistically insignificant) and for all retailers is $-0.27 \%$ (significant at the $5 \%$ level). 


\section{REFERENCES}

Abdel-khalik, A.R., (1981). The Economic Effects on Lessees of FASB Statement No. 13, Accounting for Leases, Stamford, CT, Financial Accounting Standards Board.

ASB (1999). Leases: Implementation of a New Approach, Discussion Paper, London, Accounting Standards Board.

ASC (1984). Accounting for Leases and Hire Purchase Contracts, Statement of Standard Accounting Practice No. 21, London, Accounting Standards Committee.

Ashton, R.K. (1985). 'Accounting for finance leases: a field test'. Accounting and Business Research, 15, Summer, pp. 233-238.

Ball, R., Thomas, R.E. \& McGrath, J. (1991). 'Influence of R\&D accounting conventions on internal decision-making of companies', $R \& D$ Management, 21 (4), pp. 261-269.

Barnes, P. (1987). 'The analysis and use of financial ratios: a review article'. Journal of Business Finance \& Accounting, 14(4), Winter, pp. 449-461.

Beattie, V.A., Edwards, K. \& Goodacre, A. (1998). 'The impact of constructive operating lease capitalisation on key accounting ratios', Accounting and Business Research, 28 (4), Autumn, pp. 233-254.

Beattie, V.A., Goodacre, A. \& Thomson, S. (2000a). 'Operating leases and the assessment of lease-debt substitutability', Journal of Banking \& Finance, 24 (3), pp. 427-470.

Beattie, V.A., Goodacre, A. \& Thomson, S. (2000b). Recognition versus disclosure: an investigation of the impact on equity risk using UK operating lease disclosures', Journal of Business Finance \& Accounting, 27 (9\&10), November/December, pp. 1185-1224.

Beattie, V.A., Goodacre, A. \& Thomson, S. (2001a). 'Lease accounting reform: the views of UK finance directors', paper presented at the British Accounting Association Annual Conference 2001, Nottingham, 26-28 March.

Beattie, V.A., Goodacre, A. \& Thomson, S. (2001b). Leasing and ørporate financing decisions, unpublished manuscript.

Blake, J. (1992). 'A classification system for economic consequences issues in accounting regulation', Accounting and Business Research, 22 (88), Autumn, pp. 305-321.

BPF/IPD (1999). Annual Lease Review 1999, London, British Property Federation/Investment Property Databank.

Breton, G. \& Taffler, R.J. (1995). 'Creative accounting and investment analyst response', Accounting and Business Research, 25 (98), pp. 81-92.

Dresdner Kleinwort Benson (1998). Operating leases: the retail house of cards, London, Dresdner Kleinwort Benson Research.

Drury, C. \& Braund, S. (1990). 'The leasing decision: a comparison of theory and practice', Accounting and Business Research, 20 (79), Summer, pp. 179-191.

Dukes, R. (1976). 'An investigation of the effects of expensing research and development costs on security prices' In M. Schiff \& G. Sorter (eds), Proceedings of the Conference on Topical Research in Accounting, pp. 147-193, New York University, New York, Ross Institute of Accounting Research, School of Business. 
Dukes, R., Dyckman, T. \& Elliot, J. (1980). 'Accounting for research and development costs: the impact on research and development expenditures', Journal of Accounting Research, 18 (Supplement), pp. 1-26.

El-Gazzar, S.M. (1993). 'Stock market effects of the closeness to debt covenant restrictions resulting from capitalization of leases', Accounting Review, 68 (2), April, pp. 258-272.

Elliot, J., Richardson, G., Dyckman, T. \& Dukes, R. (1984). 'The impact of SFAS No 2 on firm expenditures on research and development: replications and extensions', Journal of Accounting Research, 22, Spring, pp. 85-102.

Ely, K.M. (1995). 'Operating lease accounting and the market's assessment of equity risk', Journal of Accounting Research, 33 (2), Autumn, pp. 397-415.

Finance \& Leasing Association (1999). 'Think again Sir David: lease accounting reform is not as simple as you think', Press Release: 17 December, London, Finance \& Leasing Association.

Finance \& Leasing Association (2000). Annual survey of business finance 2000, London, Finance \& Leasing Association.

Gallery, G. \& Imhoff, E.A. (1998). 'Disclosure versus recognition: some evidence from the Australian capital market regarding off-balance sheet leasing'. Paper presented at the University of Melbourne, Research Seminar Series.

Garrod, N. (1989). 'Regulation and response: the case of lease disclosure in the UK'. Research in Accounting Regulation, 3, pp. 69-92.

Godfrey, J.M. and Warren. S.M. (1995). 'Lessee reactions to regulation of accounting for leases', Abacus, 31 (2), September, pp. 201-228.

Goodacre, A. \& Beattie, V.A. (1999). 'Operating leases get the treatment', Professional Investor, October, pp. 24-27.

Gopalakrishnan, V. \& Parkash, M. (1996). 'The debt-equivalency of recognized vs. disclosed obligations: an examination of borrower and lender perceptions', Research in Accounting Regulation, 10, pp. 63-77.

Gopalakrishnan, V. \& Sugrue, T.F. (1992). 'Economic consequences of pension policy deliberations (SFAS no. 87): an empirical assessment of debt-covenant hypothesis', Journal of Business Finance \& Accounting, 19 (5), September, pp.751-775.

Holthausen, R.W. \& Leftwich, R.W. (1983). 'The economic consequences of accounting choice: implications of costly contracting and monitoring', Journal of Accounting and Economics, 5 (2) pp. 77-117.

Horwitz, B.N. \& Kolodny, R. (1980). 'The economic effects of involuntary uniformity in the financial reporting of R\&D expenditures', Journal of Accounting Research, 18 (Supplement), pp. 38-74.

Imhoff, E.A. \& Thomas, J.K. (1988). 'Economic consequences of accounting standards: the lease disclosure rule change', Journal of Accounting and Economics, 10 (4), pp. 277-310.

Imhoff, E.A., Lipe, R.C. \& Wright, D.W. (1991). 'Operating leases: impact of constructive capitalization', Accounting Horizons, 5(1), March, pp. 51-63.

Imhoff, E.A., Lipe, R.C. \& Wright, D.W. (1993), 'The effects of recognition versus disclosure on shareholder risk and executive compensation', Journal of Accounting, Auditing and Finance, 8 (4), Fall, pp. 335-368. 
Imhoff, E.A., Lipe, R.C. \& Wright, D.W. (1997). 'Operating leases: income effects of constructive capitalization', Accounting Horizons, 11(2), June, pp. 12-32.

Investment Property Forum (1999). 'Proposed capitalisation of operating leases - what impact on the UK property market?', Forum Review, Issue No. 3 October, pp. 2-3.

KPMG (2000). 'Approach with caution', Financial Reporting Update, January/February, pp. 1-2.

Larcker, D.F. \& Revsine, L. (1983). 'The oil and gas accounting controversy: an analysis of economic consequences', Accounting Review, 58 (4), October, pp. 706-732.

Mayer-Sommer, A.P. (1979). 'Understanding and acceptance of the efficient markets hypothesis and its accounting implications', Accounting Review, 54 (1), January, pp. 88106.

McGregor, W. (1996). Accounting for Leases: A New Approach, Stamford, CT, Financial Accounting Standards Board.

Munter, P. \& Ratcliffe, T.A. (1983). 'An assessment of user reactions to lease accounting disclosure', Journal of Accounting, Auditing and Finance, 6 (2), pp. 108-114.

Nelson, A.J. (1963). 'Capitalising leases - the effect on financial ratios', Journal of Accountancy, July, pp. 49-58.

Nelson, F. (1999), 'Trouble in store for high street retailers', The Times, 4 December, p. 31.

Odaiyappa, R. and Nainar, S.M.K. (1992). 'Economic consequences of SFAS No 33 - an insider-trading perspective', Accounting Review, 67 (3), July, pp. 599-609.

Prakash, P. \& Rappaport, A. (1977). 'Information inductance and its significance for accounting', Accounting, Organisations and Society, 2 (1), pp. 29-38.

Ringer, M. \& Unerman, J. (2000). 'Hidden gearing', Accountancy, June, pp. 104-105.

Ro, B.T. (1978). 'The disclosure of capitalised lease information and stock prices', Journal of Accounting Research, 16 (2), Autumn, pp. 315-340.

Schipper, K. (1994). 'Academic accounting research and the standard setting process'. Accounting Horizons, 8 (4), December, pp. 61-73.

Shehata, M. (1991). 'Self-selection bias and the economic consequences of accounting regulation: an application of two-stage switching regression to SFAS no. 2', Accounting Review, 66 (4), October, pp. 768-787.

Taylor, P. \& Turley, S. (1985). 'The views of management on accounting for leases', Accounting and Business Research, 16, Winter, pp. 59-67.

Vigeland, R.L. (1981). 'The market reaction to SFAS no. 2', Accounting Review, April, pp. 309-325.

Wasley, C.E. \& Linsmeier, T.J. (1992). 'A further examination of the economic consequences of SFAS no.2', Journal of Accounting Research, 30 (1), Spring, pp. 156-164.

Wilkins, T. \& Zimmer, I. (1983a). 'The effect of leasing and different methods of accounting for leases on credit evaluations', Accounting Review, 58 (4), pp. 749-764.

Wilkins, T. \& Zimmer, I. (1983b). 'The effect of alternative methods of accounting for leases - an experimental study', Abacus, 19 (1), pp. 64-75. 
Wilkins, T. (1984). 'A behavioural investigation of alternative methods of financing capital acquisitions and lease capitalization', Accounting and Business Research, 14 (56), Autumn, pp. 359-366.

Zeff, S.A. (1978). "The rise of "economic consequences"', Journal of Accountancy, December, pp. 56-63. 
TABLE 1

Definitions of key performance ratios and the impact of operating lease capitalisation

\begin{tabular}{|c|c|c|c|}
\hline \multirow[t]{2}{*}{ Ratio } & \multirow[t]{2}{*}{ Definition (pre-capitalisation) } & \multicolumn{2}{|c|}{ Impact of capitalisation } \\
\hline & & Sign & Ratio definition \\
\hline Profit margin & $\begin{array}{l}\text { Earnings before interest \& tax (EBIT) } \\
\text { Sales }\end{array}$ & + & $\underline{\text { SBIT }}_{\text {pre }}+$ OLR - depn \\
\hline $\begin{array}{l}\text { Return on equity } \\
\text { (ROE) }\end{array}$ & $\frac{\text { Profit after interest \& tax (PAIT) }}{\text { Equity }\left(\mathrm{E}_{\text {Ashton }}\right)}$ & + or - & $\frac{\underline{P A I T}_{\text {pre }}}{\mathrm{E}_{\text {Ashton, pre }}-\left(\mathrm{PV}_{\mathrm{L}}-\mathrm{PV}_{\mathrm{A}}\right)}$ \\
\hline $\begin{array}{l}\text { Return on assets } \\
\text { (ROA) }\end{array}$ & $\frac{\text { Profit after interest \& } \operatorname{tax}(\text { PAIT) }}{\text { Total assets (TA) }}$ & - & $\frac{\underline{P A I T}_{\text {pre }}}{\mathrm{TA}_{\text {pre }}}+\frac{+(1-\mathrm{T})(\mathrm{OLR}-\text { depn }- \text { int })}{\mathrm{PV}_{\mathrm{A}}}$ \\
\hline $\begin{array}{l}\text { Return on capital } \\
\text { employed (ROCE) }\end{array}$ & $\begin{array}{l}\text { Earnings before interest \& tax (EBIT) } \\
\text { Capital employed }(\mathrm{CE})\end{array}$ & + or - & $\frac{\underline{E B I T}_{\text {pre }}+\text { OLR }- \text { depn }}{\mathrm{CE}_{\text {pre }}+\mathrm{PV}_{\mathrm{A}}-\left[\mathrm{OLR}-\mathrm{i} \times \mathrm{PV}_{\mathrm{L}}\right]}$ \\
\hline Asset turnover & 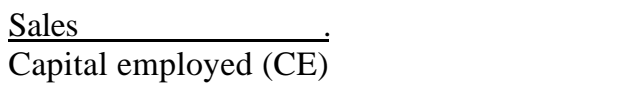 & - & $\frac{\text { Sales }}{\mathrm{CE}_{\text {pre }}+\mathrm{PV}_{\mathrm{A}}-\left[\mathrm{OLR}-\mathrm{i} \times \mathrm{PV}_{\mathrm{L}}\right]}$ \\
\hline Interest cover & $\frac{\text { Earnings before interest \& tax (EBIT) }}{\text { Interest (I) }}$ & + or - & $\frac{\mathrm{EBIT}_{\text {pre }}}{\mathrm{I}_{\mathrm{pre}}+\mathrm{int}}$ \\
\hline Gearing $_{\text {Ashton }}$ & $\frac{\text { Long-term debt (LTD) }}{\text { Capital employed (CE) }}$ & + & $\frac{\left.\mathrm{LTD}_{\text {pre }}+\mathrm{PV}_{\mathrm{L}}-\frac{\mathrm{OLLR}-\mathrm{i} \times \mathrm{PV}}{\mathrm{CE}} \mathrm{Pre}\right]}{\mathrm{PV}_{\mathrm{A}}-\left[\mathrm{OLR}-\mathrm{i} \times \mathrm{PV}_{\mathrm{L}}\right]}$ \\
\hline Gearing $_{\text {ILW }}$ & $\frac{\text { Total debt (D) }}{\text { Equity }\left(\mathrm{E}_{\mathrm{ILW}}\right)}$ & + & 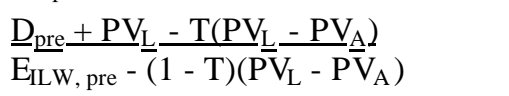 \\
\hline $\begin{array}{l}\text { Gearing } \\
\text { (net debt to equity) }\end{array}$ & $\frac{\text { Total borrowings - cash \& equivalents (TB) }}{\text { Equity }\left(\mathrm{E}_{\mathrm{LW}}\right)}$ & + & 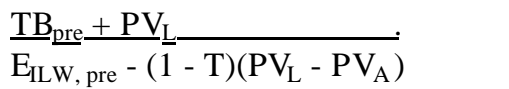 \\
\hline
\end{tabular}

\footnotetext{
OLR = annual operating lease rental (for consistency with asset and liability estimates, this was taken as next year's operating lease commitment, as specified in the notes to the accounts, rather that the current year reported operating lease rental);

depn $\quad=$ annual straight line depreciation of capitalised asset;

$\mathrm{T}=$ company-specific effective tax rate;

$\mathrm{PV}_{\mathrm{L}} \quad=$ estimated operating lease liability based on the present value of minimum lease payments discounted at $\mathrm{i} \%$;

$\mathrm{PV}_{\mathrm{A}} \quad=\quad$ estimated operating lease asset derived using the relationship:

$\mathrm{PV}_{\mathrm{A}} / \mathrm{PV} \mathrm{L}=\left(\mathrm{RL} \times \mathrm{PVAF} \mathrm{F}_{\mathrm{i}, \mathrm{TL}}\right) /\left(\mathrm{TL} \times \mathrm{PVAF} \mathrm{F}_{\mathrm{i}, \mathrm{RL}}\right)$, where $\mathrm{RL}$ and $\mathrm{TL}$ are remaining and total lease lives, and $\mathrm{PVAF}_{\mathrm{i}, \mathrm{n}}$ is the present value of an annuity for $\mathrm{n}$ years discounted at $\mathrm{i} \%$ (see footnote 6 );

int $\quad=$ annual lease interest expense $\left.=\mathrm{i} \times\left(\mathrm{PV}_{\mathrm{L}}+\mathrm{OLR}\right)\right] /(1+\mathrm{i})$;

$\mathrm{i} \quad=$ rate of interest for discounting minimum lease payments;

$\mathrm{T}\left(\mathrm{PV}_{\mathrm{L}}-\mathrm{PV}_{\mathrm{A}}\right)=$ reduction in deferred tax due to operating lease capitalisation

OLR $-\mathrm{i} \times \mathrm{PV}_{\mathrm{L}}=$ short-term portion of lease liability

[This short-term operating lease liability is incorrectly calculated as OLR/(1+ i) in BEG (1998)]
} 
TABLE 2

Estimated value of operating lease assets and liabilities for 1999

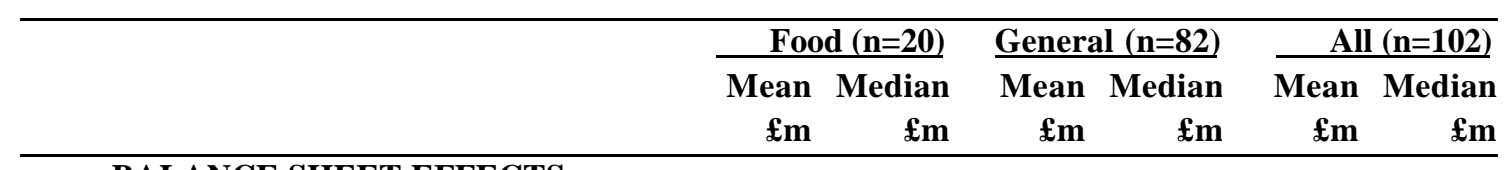

BALANCE SHEET EFFECTS

\section{Operating leases}

Liability due within 1 year

A Liability due after more than 1 year

B Total liability

C Long-term debt (excl op leases)

A/C Lease liability/debt ${ }^{1}$

Lease asset: plant and equipment

Lease asset: land and buidings

D Total lease asset

E Total assets (excl op leases)

D/E Lease asset/total asset ${ }^{2}$

\section{Finance leases (reported)}

Liability due within 1 year

Liability due after more than 1 year

F Total liability

B/F Op leases/fin leases

\section{INCOME EFFECTS}

Operating profit (EBIT) reported

Operating profit post-capitalisation

Percentage change ${ }^{2}$

Net profit (profit after tax) reported

Net profit post-capitalisation

Percentage change ${ }^{2}$

\begin{tabular}{rrrrrr}
13.4 & 3.5 & 12.2 & 2.8 & 12.4 & 2.8 \\
273.9 & 62.6 & 209.5 & 57.5 & 222.1 & 57.5 \\
\hline 287.3 & 66.1 & 221.7 & 59.9 & 234.5 & 59.9 \\
\hline 172.9 & 15.2 & 40.9 & 1.6 & 66.8 & 1.8 \\
& & & & & \\
1.58 & 2.87 & 5.12 & 9.11 & 3.32 & 6.64
\end{tabular}

\begin{tabular}{rrrrrr}
9.0 & 0.8 & 3.0 & 0.3 & 4.2 & 0.4 \\
212.9 & 48.5 & 169.0 & 45.9 & 177.6 & 45.9 \\
\hline 221.9 & 51.3 & 172.0 & 46.0 & 181.8 & 46.0 \\
\hline & & & & & \\
1408.7 & 131.2 & 464.5 & 65.7 & 649.7 & 76.6
\end{tabular}

$\begin{array}{llllll}0.16 & 0.34 & 0.37 & 0.55 & 0.28 & 0.52\end{array}$

\begin{tabular}{rrrrrr}
2.1 & 0.1 & 1.0 & 0.0 & 1.2 & 0.0 \\
8.7 & 0.1 & 4.4 & 0.0 & 5.2 & 0.0 \\
\hline 10.8 & 0.1 & 5.4 & 0.0 & 6.4 & 0.0 \\
\hline & & & & & \\
26.6 & & 41.1 & & 36.6 &
\end{tabular}

$\begin{array}{rrrrrr}147.4 & 14.5 & 51.5 & 9.9 & 70.3 & 10.5 \\ 167.4 & 21.6 & 66.9 & 13.1 & 86.6 & 14.4 \\ 13.6 & 15.6 & 29.9 & 28.2 & 23.2 & 24.1 \\ & & & & & \\ 89.6 & 9.3 & 32.7 & 6.4 & 43.9 & 6.7 \\ 85.8 & 7.7 & 29.7 & 4.9 & 40.7 & 5.2 \\ -4.2 & -5.1 & -9.2 & -8.4 & -7.3 & -7.7\end{array}$

Notes

1. Median lease liability/debt ratio is based on individual company figures; several companies with zero long-term debt are excluded from the calculation: 3 (food), 22 (general), 25 (all).

2. Median lease liability/debt ratio is based on individual company figures. 
TABLE 3

Changes in median ratios following lease capitalisation for 1999

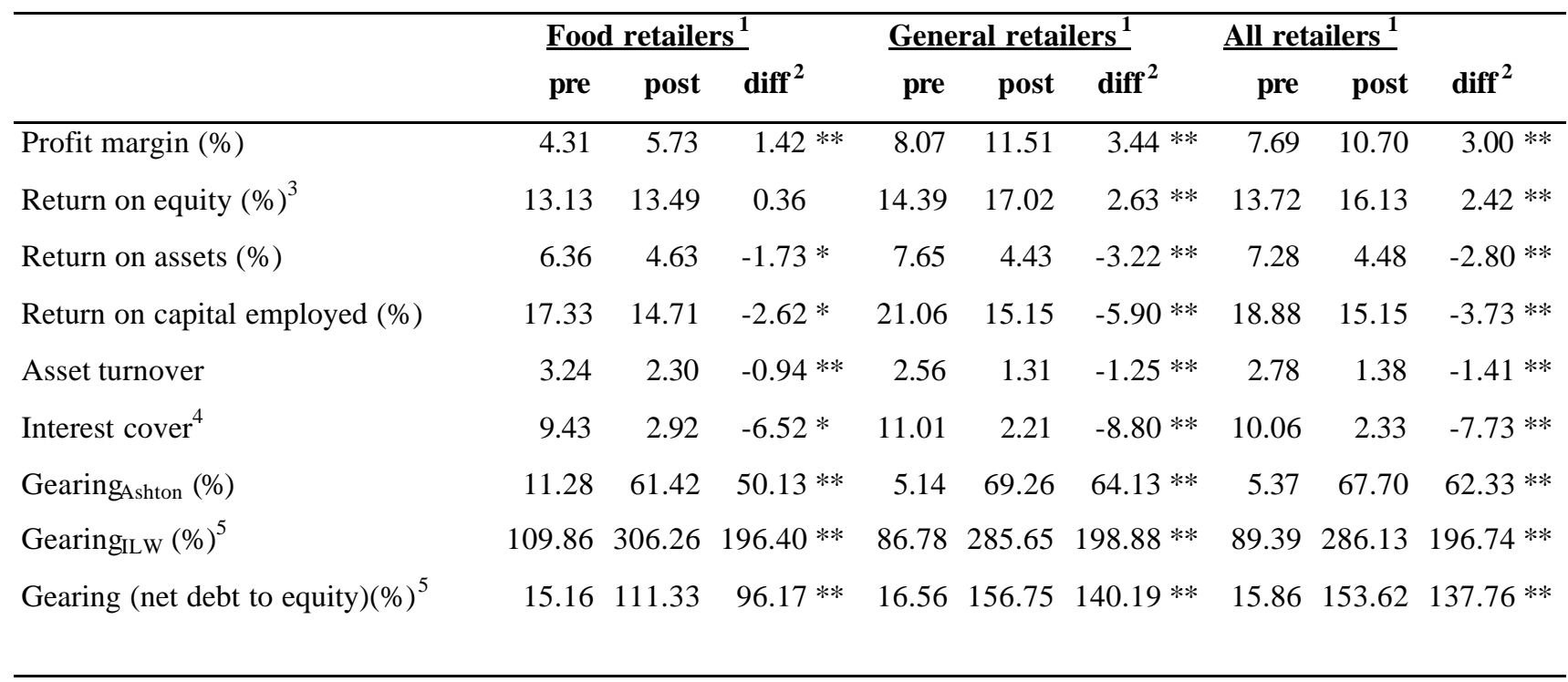

Notes

1. With the general exclusion of 4 companies having negative equity pre-capitalisation, the results are for sample sizes of 18 (food), 80 (general) and 98 (all) except as indicated.

2. $\quad$ diff $=$ post - pre; $* *(*)=$ significance at $1 \%(5 \%)$ level of two-tailed Wilcoxon signed ranks test of difference in medians.

3. Excludes companies having negative equity post-capitalisation: 1 (food), 14 (general), 15 (all).

4. Excludes companies having no interest pre-capitalisation: 8 (general), 8 (all).

5. Excludes companies having negative equity post-capitalisation: 1 (food), 11 (general), 12 (all). For the last two gearing measures, deferred tax is effectively treated as a liability and, since capitalisation generally reduces deferred tax, overall debt is reduced. Further, equity is affected by the cumulative net of tax profit reduction. Thus, there are fewer companies having negative debt post-capitalisation than for the Return on equity measure, which treats deferred tax as equity. 
TABLE 4

Correlations between ratios pre- and post-operating leases capitalisation for 1999

\begin{tabular}{|c|c|c|c|c|c|c|}
\hline \multirow{3}{*}{$\frac{}{\text { Profit margin (\%) }}$} & \multicolumn{2}{|c|}{ Food retailers ${ }^{1,2}$} & \multicolumn{2}{|c|}{ General retailers $^{1,2}$} & \multicolumn{2}{|c|}{$\underline{\text { All retailers }} 1,2$} \\
\hline & Spearman & Pearson & Spearman & Pearson & Spearman & Pearson \\
\hline & 0.816 & 0.973 & 0.864 & 0.883 & 0.871 & 0.921 \\
\hline Return on equity $(\%)^{3}$ & 0.912 & 0.989 & 0.973 & 0.438 & 0.974 & 0.434 \\
\hline Return on assets (\%) & 0.639 & 0.929 & 0.835 & 0.868 & 0.805 & 0.880 \\
\hline Return on capital employed (\%) & 0.827 & 0.958 & 0.901 & 0.870 & 0.894 & 0.875 \\
\hline Asset turnover & 0.655 & 0.670 & 0.470 & 0.549 & 0.518 & 0.511 \\
\hline Interest cover ${ }^{4}$ & 0.645 & 0.837 & 0.465 & 0.369 & 0.480 & $0.086 \mathrm{~ns}$ \\
\hline Gearing $_{\text {Ashton }}(\%)$ & $0.181 \mathrm{~ns}$ & $0.295 \mathrm{~ns}$ & $0.098 \mathrm{~ns}$ & $0.168 \mathrm{~ns}$ & $0.075 \mathrm{~ns}$ & $0.170 \mathrm{~ns}$ \\
\hline Gearing $_{\text {ILW }}(\%)^{5}$ & 0.713 & 0.712 & 0.663 & $0.171 \mathrm{~ns}$ & 0.642 & $0.160 \mathrm{~ns}$ \\
\hline Gearing (net debt to equity)(\%) ${ }^{5}$ & $0.294 \mathrm{~ns}$ & 0.575 & $0.151 \mathrm{~ns}$ & $0.017 \mathrm{~ns}$ & $0.172 \mathrm{~ns}$ & $0.016 \mathrm{~ns}$ \\
\hline
\end{tabular}

Notes

1. With the general exclusion of 4 companies having negative equity pre-capitalisation, the results are for sample sizes of 18 (food), 80 (general) and 98 (all) except as indicated.

2. $\mathrm{ns}=$ not significantly different from zero at $5 \%$ level (two-tailed) .

3. Excludes companies having negative equity post-capitalisation: 1 (food), 14 (general), 15 (all).

4. Excludes companies having no interest pre-capitalisation: 8 (general), 8 (all).

5. Excludes companies having negative equity post-capitalisation: 1 (food), 11 (general), 12 (all). For the last two gearing measures, deferred tax is effectively treated as a liability and, since capitalisation generally reduces deferred tax, overall debt is reduced. Further, equity is affected by the cumulative net of tax profit reduction. Thus, there are fewer companies having negative debt post-capitalisation than for the Return on equity measure, which treats deferred tax as equity. 
TABLE 5

Comparison with other sectors: estimated mean value of operating lease assets and liabilities for 1994

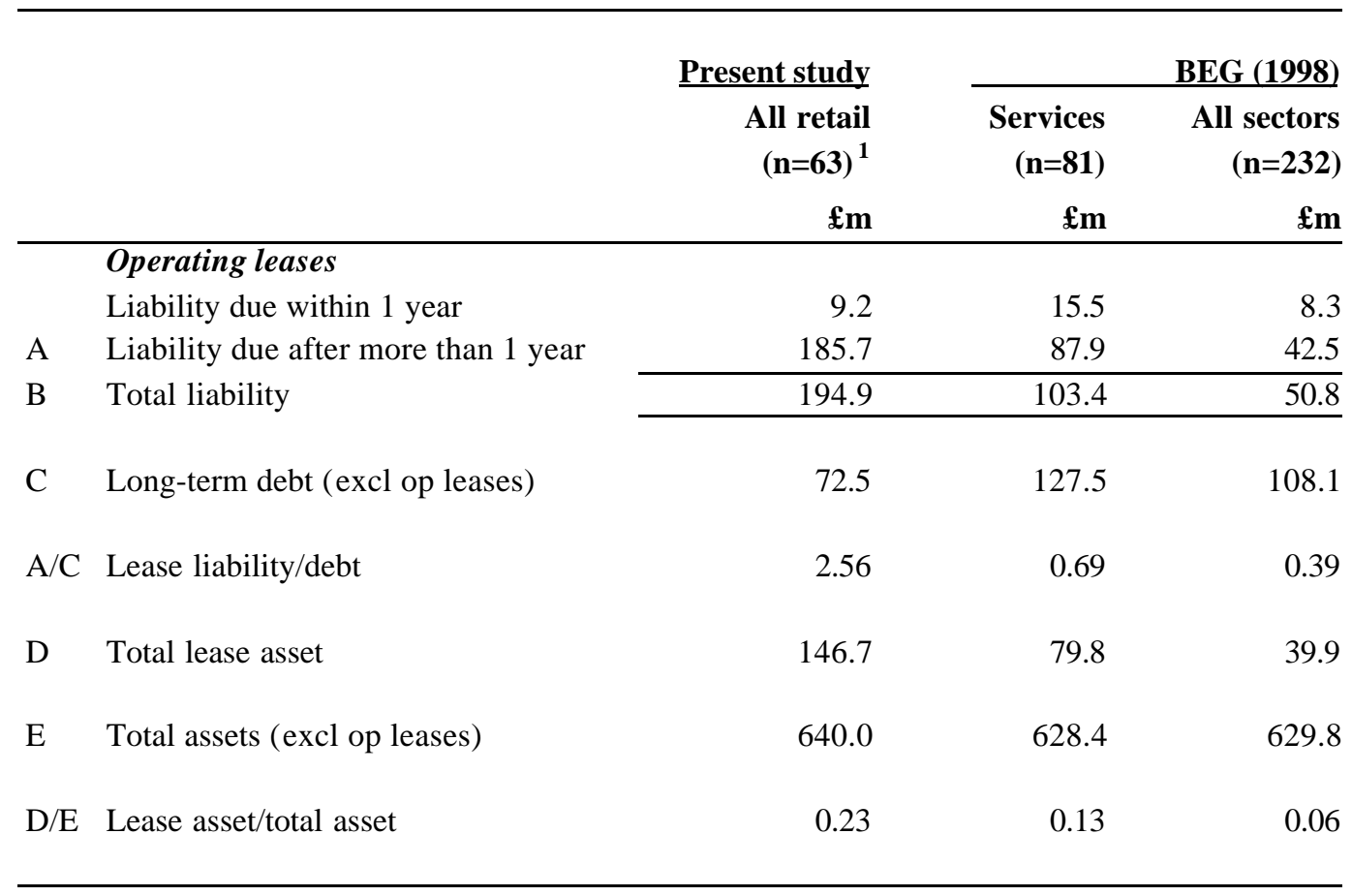

Notes

1. This sub-sample represents the 63 retail companies, from the original sample of 102 , that existed in 1994 [see comment in text concerning survivorship bias]. A discount rate of $10 \%$ is used here for consistency with the BEG (1998) study.

2. The details for other sectors are extracted from BEG (1998), Table 6, p. 247. 
TABLE 6

\section{Comparison with previous studies on operating lease capitalisation}

\begin{tabular}{|c|c|c|c|}
\hline Study & $\underline{\text { Present study }}{ }^{1}$ & BEG $(1998)^{2}$ & $\underline{\operatorname{ILW}(1991)^{3}}$ \\
\hline Sector covered & All retailers & All sectors & Sundry \\
\hline Country & UK & UK & \\
\hline Sample size & $\mathrm{n}=98^{4}$ & $n=232$ & $\pi-$ \\
\hline Financial statement year & 1999 & 1994 & 19 \\
\hline
\end{tabular}

\section{Percentage change in mean ratio following capitalisation}

Profit margin (\%)

Return on equity $(\%)^{5}$

Return on assets (\%)

Return on capital employed (\%)

Asset turnover

Interest cover $^{6}$

Gearing $_{\text {Ashton }}(\%)$

$\operatorname{Gearing}_{\text {ILW }}(\%)^{7}$

Gearing (net debt to equity) $(\%)^{8}$

$$
\begin{array}{r}
51.4 * * \\
35.1 * * \\
-44.8 * * \\
-32.8 * * \\
-55.2 * * \\
-79.3 * * \\
433.2 * * \\
295.0 * * \\
2246.0 * *
\end{array}
$$

$12.1 * *$

$4.8 *$

na

na

$-10.8 * *$

$-22.0$

$-0.6$

$-12.5 * *$

na

na

$-25.9$

$92.8 * *$

na

na

$48.7 * *$

119.0

$260.0 * *$

Notes

1. Changes in means (rather than medians) are reported in this table for consistency with prior studies, but extreme outliers are removed to avoid distortions (see below for impact of outliers). A discount rate of $10 \%$ is used here for consistency with the BEG (1998) and ILW (1991) studies.

2. Figures reported in BEG (1998), Table 8, p. 249.

3. Derived from figures reported in ILW (1991), p. 61; no statistical tests of significance were reported.

4. Number of companies is 98 except for those ratios affected by negative equity, zero pre-capitalisation interest and extreme outliers: ROE $(n=74)$, interest cover $(n=79)$, gearing $\operatorname{ILW}_{(\mathrm{W}}(n=83)$, net debt to equity $(\mathrm{n}=83)$.

5. Including 9 outliers gave a percentage change of $61.3 \%$ in ROE.

6. Including 11 outliers gave a percentage change of $-98.3 \%$ in interest cover.

7. Including 3 outliers gave a percentage change of $517.5 \%$ in gearing ILW $_{\text {. }}$

8. Including 3 outliers gave a percentage change of $4271.3 \%$ in net debt to equity.

9. na $=$ ratio not included in study; $* *(*)=$ significance at $1 \%(5 \%)$ level of a two-tailed paired t-test. 
TABLE 7

Effect of managers' response to lease capitalisation Estimated value of operating lease assets and liabilities for 1999 assuming re-negotiation of long contracts to renewable five-year terms

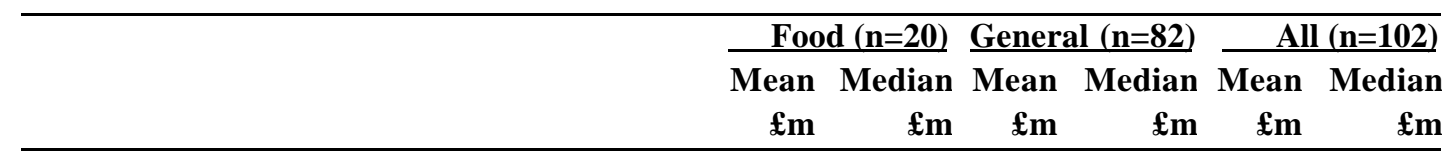

\section{BALANCE SHEET EFFECTS}

\section{Operating leases}

Liability due within 1 year

\begin{tabular}{rrrrrr}
29.8 & 7.2 & 24.5 & 5.9 & 25.5 & 5.9 \\
64.5 & 15.4 & 52.5 & 13.0 & 54.9 & 13.0 \\
\hline 94.3 & 22.7 & 77.0 & 18.9 & 80.4 & 18.9 \\
\hline & & & & & \\
172.9 & 15.2 & 40.9 & 1.6 & 66.8 & 1.8 \\
& & & & & \\
0.37 & 0.85 & 1.28 & 2.19 & 0.82 & 1.72
\end{tabular}

Lease asset: plant and equipment

Lease asset: land and buidings

D Total lease asset

\begin{tabular}{rrrrrr}
7.2 & 0.8 & 2.9 & 0.3 & 3.8 & 0.3 \\
80.1 & 18.5 & 68.5 & 17.4 & 70.7 & 17.4 \\
\hline 87.3 & 21.0 & 71.4 & 17.5 & 74.5 & 17.5 \\
\hline
\end{tabular}

E Total assets (excl op leases)

$1408.7 \quad 131.2 \quad 464.5$

$\begin{array}{lll}65.7 & 649.7 \quad 76.6\end{array}$

D/E Lease asset/total asset ${ }^{2}$

$\begin{array}{llllll}0.06 & 0.14 & 0.15 & 0.22 & 0.11 & 0.20\end{array}$

\section{INCOME EFFECTS}

Percentage change in operating profit ${ }^{2}$

$\begin{array}{rrrrrr}5.3 & 20.7 & 12.2 & 8.1 & 9.4 & 9.5 \\ -1.9 & -7.5 & -4.6 & -7.8 & -3.6 & -10.5\end{array}$

Notes

1. Median lease liability/debt ratio is based on individual company figures; several companies with zero long-term debt are excluded from the calculation: 3 (food), 22 (general), 25 (all).

2. Median lease liability/debt ratio is based on individual company figures. 
TABLE 8

\section{Effect of managers' response to lease capitalisation Changes in median ratios following lease capitalisation for 1999 assuming re-negotiation of long contracts to renewable five-year terms}

\begin{tabular}{|c|c|c|c|c|c|c|c|c|c|}
\hline & \multicolumn{3}{|c|}{ Food retailers ${ }^{1}$} & \multicolumn{3}{|c|}{ General retailers ${ }^{T}$} & \multicolumn{3}{|c|}{ All retailers ${ }^{T}$} \\
\hline & pre & post & $\operatorname{diff}^{2}$ & pre & post & $\operatorname{diff}^{2}$ & pre & post & $\operatorname{diff}^{2}$ \\
\hline Profit margin (\%) & 4.31 & 5.22 & $0.90 * *$ & 8.07 & 9.90 & $1.83 * *$ & 7.69 & 8.43 & $0.74 * *$ \\
\hline Return on equity $(\%)^{3,5}$ & 13.13 & 13.06 & $-0.07 * *$ & 16.39 & 16.17 & $-0.22 * *$ & 15.48 & 14.32 & $-1.16 * *$ \\
\hline Return on assets (\%) & 6.36 & 5.15 & $-1.21 *$ & 7.65 & 5.74 & $-1.91 * *$ & 7.28 & 5.42 & $-1.86 * *$ \\
\hline Return on capital employed (\%) & 17.33 & 17.11 & -0.22 & 21.06 & 18.98 & $-2.08 * *$ & 18.88 & 18.08 & $-0.80 * *$ \\
\hline Asset turnover & 3.24 & 2.83 & $-0.41 * *$ & 2.56 & 2.07 & $-0.49 * *$ & 2.78 & 2.24 & $-0.54 * *$ \\
\hline Interest cover ${ }^{4}$ & 9.43 & 4.79 & $-4.64 *$ & 11.01 & 3.43 & $-7.58 * *$ & 10.06 & 3.59 & $-6.48 * *$ \\
\hline Gearing $_{\text {Ashton }}(\%)$ & 11.28 & 29.72 & $18.44 * *$ & 5.14 & 32.55 & $27.41 * *$ & 5.37 & 32.29 & $26.92 * *$ \\
\hline Gearing $_{\text {ILW }}(\%)^{5}$ & 109.86 & 149.59 & $45.67 * *$ & 92.06 & 160.21 & $68.15 * *$ & 92.88 & 155.27 & $62.39 * *$ \\
\hline Gearing (net debt to equity) $(\%)^{5}$ & 15.16 & 50.87 & $40.79 * *$ & 16.26 & 61.03 & $44.77 * *$ & 15.56 & 57.16 & $41.60 * *$ \\
\hline
\end{tabular}

Notes

1. With the general exclusion of 4 companies having negative equity pre-capitalisation, the results are for sample sizes of 18 (food), 80 (general) and 98 (all) except as indicated.

2. $\quad$ diff $=$ post - pre; $* *(*)=$ significance at $1 \%(5 \%)$ level of two-tailed Wilcoxon signed ranks test of difference in medians.

3. Excludes companies having negative equity post-capitalisation: 1 (general), 1 (all).

4. Excludes companies having no interest pre-capitalisation: 8 (general), 8 (all).

5. The reduced number of general (and all) retailers having negative equity post-capitalisation gives increased sample sizes for these three ratios. In turn, this affects the pre-capitalisation ratios, which therefore differ from those reported in Table 3. 